Article

\title{
Mono- and Dimeric Xanthones with Anti-Glioma and Anti-Inflammatory Activities from the Ascidian-Derived Fungus Diaporthe sp. SYSU-MS4722
}

\author{
Senhua Chen ${ }^{1,2}\left(\mathbb{D}\right.$, Heng Guo ${ }^{1,2}$, Minghua Jiang ${ }^{1,2} \mathbb{D}$, Qilin Wu ${ }^{1,2}$, Jing Li ${ }^{1,2}$, Hongjie Shen ${ }^{1,2, *}$ \\ and Lan Liu $1,2,3,4, *$ (iD
}

check for

updates

Citation: Chen, S.; Guo, H.; Jiang, M.; Wu, Q.; Li, J.; Shen, H.; Liu, L. Monoand Dimeric Xanthones with Anti-Glioma and Anti-Inflammatory Activities from the Ascidian-Derived Fungus Diaporthe sp. SYSU-MS4722. Mar. Drugs 2022, 20, 51. https:// doi.org/10.3390/md20010051

Academic Editors: Xuefeng Zhou and Yonghong Liu

Received: 5 December 2021

Accepted: 4 January 2022

Published: 5 January 2022

Publisher's Note: MDPI stays neutral with regard to jurisdictional claims in published maps and institutional affiliations.

Copyright: (C) 2022 by the authors. Licensee MDPI, Basel, Switzerland. This article is an open access article distributed under the terms and conditions of the Creative Commons Attribution (CC BY) license (https:// creativecommons.org/licenses/by/ $4.0 /)$.
1 School of Marine Sciences, Sun Yat-sen University, Zhuhai 519082, China; chensenh@mail.sysu.edu.cn (S.C.); guoh59@mail2.sysu.edu.cn (H.G.); jiangmh23@mail2.sysu.edu.cn (M.J.); wuqlin3@mail2.sysu.edu.cn (Q.W.); lijing356@mail.sysu.edu.cn (J.L.)

2 Southern Laboratory of Ocean Science and Engineering, Zhuhai 519082, China

3 Guangdong Provincial Key Laboratory of Marine Resources and Coastal Engineering, Zhuhai 519082, China

4 Pearl River Estuary Marine Ecosystem Research Station, Ministry of Education, Zhuhai 519082, China

* Correspondence: shenhj5@mail2.sysu.edu.cn (H.S.); cesllan@mail.sysu.edu.cn (L.L.)

\begin{abstract}
Seven new xanthones, diaporthones A-G (1-7), together with 13 known analogues, including five mono- (8-14) and six dimeric xanthones (15-20), were obtained from the ascidianderived fungus Diaporthe sp. SYSU-MS4722. Their planar structures were established by extensive spectroscopic analyses, including 1D and 2D NMR and high-resolution mass spectrometry (HRESIMS). The absolute configurations of $\mathbf{1} \mathbf{- 7}$ were clearly identified by $\mathrm{X}$-ray crystallographic analysis and calculation of the ECD Spectra. Compounds 15-20 showed significant anti-inflammatory activity with $\mathrm{IC}_{50}$ values between 6.3 and $8.0 \mu \mathrm{M}$. In addition, dimeric xanthones (15-20) showed selective cytotoxicity against $\mathrm{T} 98 \mathrm{G}$ cell lines with $\mathrm{IC}_{50}$ values ranging from 19.5 to $78.0 \mu \mathrm{M}$.
\end{abstract}

Keywords: xanthones; ascidian-derived fungus; Diaporthe sp.; anti-glioma activity

\section{Introduction}

Glioma is a fatal disease of the central nervous system having an incidence rate of 3.20 per 100,000 people [1-3]. Due to limitations of the blood-brain barrier, only four drugs, including lomustine, carmustine, temozolomide, and bevacizumab, have been approved by FDA to treat glioma in the past four decades [4,5]. Temozolomide (TMZ) as the first-line therapy drug is used for the treatment of glioma; however, at least 50\% of TMZ-treated patients and more than $90 \%$ of recurrent gliomas show no response to TMZ [6,7]. Thus, it is an urgent need to find more anti-glioma agents for the treatment of glioma. In recent years, anti-glioma molecules of marine origin have attracted many scientific research institutes or pharmaceutical companies' attention. For example, marizomib (salinosporamide A) received orphan drug designation for glioblastoma in the United States [8,9], which was discovered from the marine actinomycete Salinispora tropica [10] and Salinispora Arenicola [11] and is an irreversible proteasome inhibitor with a nanomolar range $\mathrm{IC}_{50}$ value [11]. Depatuxizumab vedotin was an antibody-drug conjugate (ADC) in phase 3 trials to treat newly diagnosed glioblastoma with EGFR amplification [8], which was developed from pentapeptide dolastatin 10 that was produced from the sea hare Dolabella Auricularia [12].

In the past five years, our research group has focused on the bioactive secondary metabolites of ascidian-derived fungi collected from the South China Sea [5,13-16]. A marine-derived fungus Diaporthe sp. SYSU-MS4722 was isolated from the South China Sea, whose EtOAc extract of a fermentation broth showed moderate anti-glioma activity. A subsequent chemical investigation led to the isolation of seven new polyketides, diaporthones $A-G(\mathbf{1}-\mathbf{7})$, together with 13 known analogues, including five mono- (8-14) and 
six dimeric xanthones (15-20) (Figure 1). Dimeric xanthones (15-20) revealed selective cytotoxicity against T98G cell lines with $\mathrm{IC}_{50}$ values ranging from 19.5 to $78.0 \mu \mathrm{M}$.<smiles>O=C1C[C@H](I)[C@H]([C@]2(CO)CC(=O)c3c(O)cccc3O2)O1</smiles><smiles>CC(=O)O[C@H]1[C@@H](C)CC(O)=C2C(=O)c3c(O)cccc3O[C@]21CO</smiles>

5<smiles>CC12C[C@H](O)[C@]3(O)C(=O)c4c(O)cccc4OC3(CO1)[C@H]2O</smiles>

8<smiles>C[C@@H]1C[C@@H](O)[C@]2(O)C(=O)c3c(O)cccc3O[C@]2(CO)[C@H]1O</smiles><smiles>CC1C[C@H](O)[C@@]2(O)C(=O)c3c(O)cccc3O[C@H]2[C@H]1O</smiles>

6<smiles>CC(=O)OC[C@]12Oc3cccc(O)c3C(=O)C1=C(O)C[C@@H](C)[C@H]2OC(C)=O</smiles><smiles>CC1=C[C@H](O)[C@]2(O)C(=O)c3c(O)cccc3O[C@]2(CO)[C@H]1O</smiles><smiles>C[C@H]1C[C@@H](O)[C@]2(O)C(=O)c3c(O)cccc3O[C@]2(CO)[C@H]1O</smiles>

$(-)-7$<smiles>C[C@@H]1C[C@@H](O)[C@]2(O)C(=O)c3c(O)cccc3O[C@]2(CO)C1=O</smiles>

10<smiles>C[C@@H]1C[C@H](O)[C@H]2C(=O)c3c(O)cccc3O[C@]2(CO)[C@H]1O</smiles><smiles>C[C@@H]1C[C@@H](O)[C@]2(O)C(=O)c3c(O)cccc3O[C@]2(CO)[C@H]1O</smiles>

$(+)-7$<smiles>C[C@@H]1CC(=O)O[C@H]1c1oc2cccc(O)c2c(=O)c1O</smiles><smiles>Cc1cc(O)cc(O)c1-c1cc(=O)c2c(O)cc(O)cc2o1</smiles>

12<smiles>[R20]C(=O)c1cc(C)cc2oc3cc([R])cc(O)c3c(=O)c12</smiles>

$13 \mathrm{R}_{1}=\mathrm{H} \quad \mathrm{R}_{2}=\mathrm{H}$ $14 \mathrm{R}_{1}=\mathrm{OH} \mathrm{R}_{2}=\mathrm{CH}_{3}$<smiles>[R]C[C@]12Oc3ccc(-c4ccc5c(c4O)C(=O)C4=C(O)C[C@H](C)[C@H](O)[C@]4(C(C)=O)O5)c(O)c3C(=O)C1=C(O)C[C@@H](C)[C@H]2OC(C)=O</smiles>

$17 \mathrm{R}=\mathrm{H}$

$18 \mathrm{R}=\mathrm{Ac}$

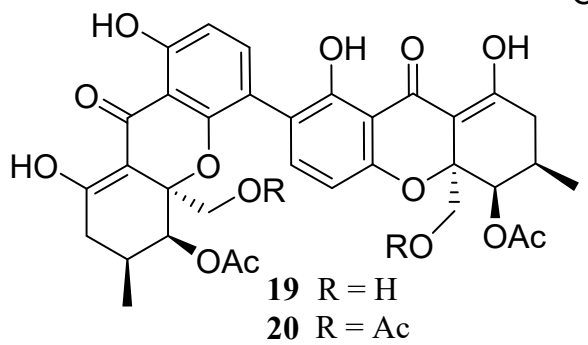

Figure 1. Chemical structures of compounds 1-20.

\section{Results and Discussion}

The EtOAc extract of marine-derived fungus Diaporthe sp. SYSU-MS4722 was performed on the repeated silica gel and Sephadex LH-20 column chromatography, followed by semipreparative HPLC to afford seven new xanthones, diaporthones $\mathrm{A}-\mathrm{H}(\mathbf{1}-\mathbf{7})$ along with 13 known analogues including seven mono- (8-14) and six dimeric xanthones $(\mathbf{1 5}-\mathbf{2 0})$. 
Diaporthone A (1) was obtained as yellow crystal, and its molecular formula was established as $\mathrm{C}_{15} \mathrm{H}_{16} \mathrm{O}_{6}$ by the negative HRESIMS ions at $m / z 291.0869[\mathrm{M}-\mathrm{H}]^{-}$(calculated for $\mathrm{C}_{15} \mathrm{H}_{15} \mathrm{O}_{6}, 291.0874$ ) (Figure S1), indicating eight degrees of unsaturation. The ${ }^{1} \mathrm{H}$ NMR (Table 1$)$ displayed three aromatic protons $\left(\delta_{\mathrm{H}} 6.40(1 \mathrm{H}, \mathrm{d}, J=8.3 \mathrm{~Hz}) ; 6.43(\mathrm{H}, J=8.3 \mathrm{~Hz})\right.$; $7.38(1 \mathrm{H}, \mathrm{t}, J=8.3 \mathrm{~Hz}))$ owing to a 1,2,3-trisubstituted benzene ring, two methines $\left(\delta_{\mathrm{H}}\right.$ $4.39(1 \mathrm{H}, \mathrm{d}, J=4.2 \mathrm{~Hz}) ; 2.85(\mathrm{H}, \mathrm{m}))$, two methylenes $\left(\delta_{\mathrm{H}} 2.22(1 \mathrm{H}, \mathrm{dd}, J=8.9,21.6 \mathrm{~Hz})\right.$, $\left.2.86(1 \mathrm{H}, \mathrm{m}) ; 3.76(2 \mathrm{H}, \mathrm{s}), \delta_{\mathrm{H}} 2.98(2 \mathrm{H}, \mathrm{br} \mathrm{s})\right)$, and one methyl $\left(\delta_{\mathrm{H}} 1.20(3 \mathrm{H}, \mathrm{d}, J=6.6 \mathrm{~Hz})\right)$. The ${ }^{13} \mathrm{C}$ NMR showed the presence of 15 carbons, which were assigned with the help of an HMBC experiment. Except for signals $\left(\delta_{C} 161.4,159.4,138.1,108.7,107.2,106.9\right)$ attributed to one aromatic ring, the other carbons were identified as one conjugated carbonyl $\left(\delta_{\mathrm{C}} 196.8\right)$, one ester carbonyl $\left(\delta_{\mathrm{C}} 177.3\right)$, and remaining six sp $\mathrm{p}^{3}$ hybridized carbons. ${ }^{1} \mathrm{H}$ and ${ }^{13} \mathrm{C}$ NMR data (Table 1 ) suggested that $\mathbf{1}$ belonged to a chromone derivative containing a $\gamma$-lactone moiety.

Table 1. ${ }^{1} \mathrm{H}(600 \mathrm{MHz})$ and ${ }^{13} \mathrm{C}(150 \mathrm{MHz}) \mathrm{NMR}$ spectroscopic data of $\mathbf{1}$ in $\mathrm{CD}_{3} \mathrm{OD}$.

\begin{tabular}{|c|c|c|c|c|c|}
\hline \multirow{2}{*}{ No. } & \multicolumn{2}{|r|}{1} & \multirow{2}{*}{ No. } & \multicolumn{2}{|r|}{1} \\
\hline & $\delta_{\mathrm{C}}$, Type & $\delta_{\mathrm{H}}$, Mult $(J$ in $\mathrm{Hz})$ & & $\delta_{\mathrm{C}}$, Type & $\delta_{\mathrm{H}}$, Mult $(J$ in $\mathrm{Hz})$ \\
\hline 2 & $83.2, \mathrm{C}$ & & $8 a$ & 159.4, C & \\
\hline 3 & 36.7, $\mathrm{CH}_{2}$ & 2.98, br s & 9 & $87.1, \mathrm{CH}$ & $4.39, \mathrm{~d}(4.2)$ \\
\hline 4 & $196.8, \mathrm{C}$ & & 10 & $29.6, \mathrm{CH}$ & $2.85, \mathrm{~m}$ \\
\hline $4 a$ & $107.2, \mathrm{C}$ & & 11 & $35.9, \mathrm{CH}_{2}$ & 2.22, dd $(21.6,8.9)$ \\
\hline 5 & $161.4, \mathrm{C}$ & & & & $2.85, \mathrm{~m}$ \\
\hline 6 & $106.9, \mathrm{CH}$ & $6.40, \mathrm{~d}(8.3)$ & 12 & $177.3, \mathrm{C}$ & \\
\hline 7 & $138.1, \mathrm{CH}$ & $7.36, \mathrm{t}(8.3)$ & 13 & $61.5, \mathrm{CH}_{2}$ & $3.76, \mathrm{~s}$ \\
\hline 8 & 108.7, CH & $6.43, \mathrm{~d}(8.3)$ & 14 & $19.4, \mathrm{CH}_{3}$ & $1.21, \mathrm{~d}(6.6)$ \\
\hline
\end{tabular}

The planar structure of 1 was identified based on the extensive 2D NMR $\left({ }^{1} \mathrm{H}-{ }^{1} \mathrm{H}\right.$ COSY, HSQC, and HMBC) (Figures S2-S7) spectroscopic data (Figure 2). The HMBC correlations from $\mathrm{H}-7$ to $\mathrm{C}-5$ and $\mathrm{C}-8 \mathrm{a}$, from $\mathrm{H}-8$ to $\mathrm{C}-4 \mathrm{a}$, from $\mathrm{H}-13$ to $\mathrm{C}-2$ and $\mathrm{C}-3$, and ${ }^{1} \mathrm{H}-{ }^{1} \mathrm{H}$ COSY of $\mathrm{H}-6 / \mathrm{H}-7 / \mathrm{H}-8$, as well as the NMR chemical shifts, complete a 4-hydroxylchromone skeleton with a hydroxymethyl group at C-2. The $\gamma$-lactone moiety with a methyl group was assigned by HMBC correlations from $\mathrm{H}-9$ to ester carbonyl C-12, from $\mathrm{H}-11$ to $\mathrm{C}-9$ and $\mathrm{C}-12$, from $\mathrm{H}-14$ to $\mathrm{C}-9, \mathrm{C}-10$ and $\mathrm{C}-11$, and the ${ }^{1} \mathrm{H}-{ }^{1} \mathrm{H}$ COSY correlations of $\mathrm{H}-9 / \mathrm{H}-$ $10 / \mathrm{H}-11$ and $\mathrm{H}-10 / \mathrm{H}-14$. The $\gamma$-lactone moiety was finally linked to $\mathrm{C}-2$ of the chromone skeleton, supported by HMBC correlations from $\mathrm{H}-13$ to $\mathrm{C}-9$ and $\mathrm{H}-9$ to $\mathrm{C}-2$.
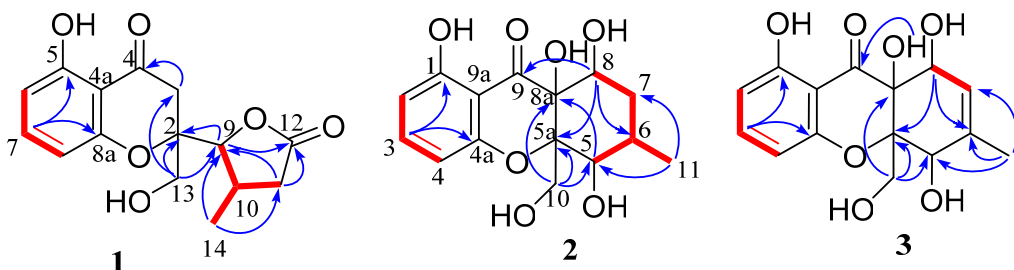

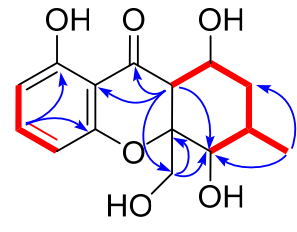

4
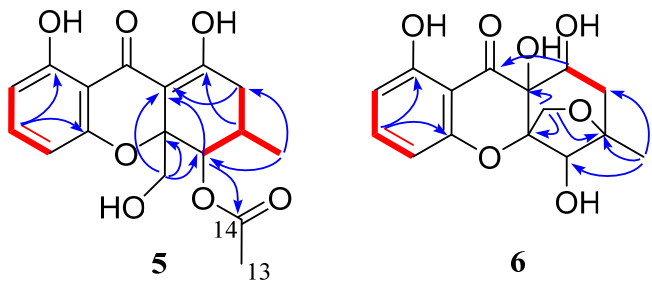

Figure 2. Key ${ }^{1} \mathrm{H}_{-}{ }^{1} \mathrm{H}$ COSY (red line) and $\mathrm{HMBC}$ (blue arrow) correlations of compounds 1-7.

The NOESY spectrum of $\mathbf{1}$ showed a correlation from $\mathrm{H}-9$ to $\mathrm{H}-14$, indicating that $\mathrm{H}-9$ and $\mathrm{H}-14$ were on the same side of the $\gamma$-lactone (Figure 3 ). The X-ray structure (Figure 4 ) 
showed that the protons $\mathrm{H}-13$ and $\mathrm{H}-9$ were located on the close position of the axis of rotation $\mathrm{C} 2-\mathrm{C} 9$, indicating that the relative configuration of 1 was $2 S^{*}, 9 S^{*}$, and $10 S^{*}$. In addition, the ECD spectrum of $(2 S, 9 S, 10 S)-1$ calculated by a quantum chemical method at the [B3LYP/6-311 $+\mathrm{G}(2 \mathrm{~d}, \mathrm{p})]$ was in good agreement with that of the experimental one (Figure 5). Thus, the absolute configuration of $\mathbf{1}$ was identified as $2 S, 9 S$, and $10 S$.

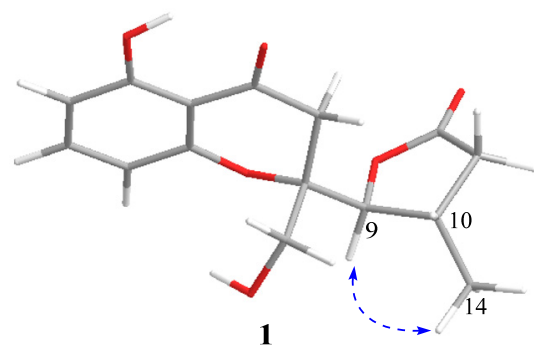

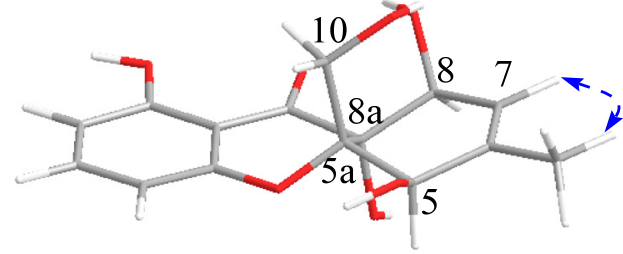

3

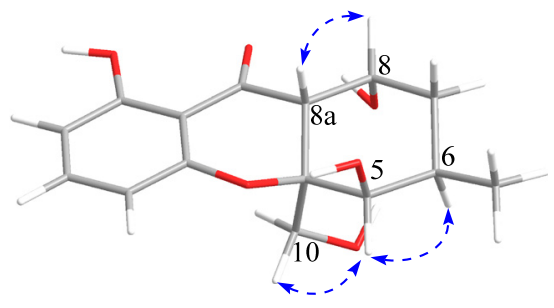

4

Figure 3. Key NOE (blue dash arrow) correlations of compounds 1, 3, and 4 (3D structures were generated by minimizing the energy using a molecular mechanics (MM2) computation by Chem3D).

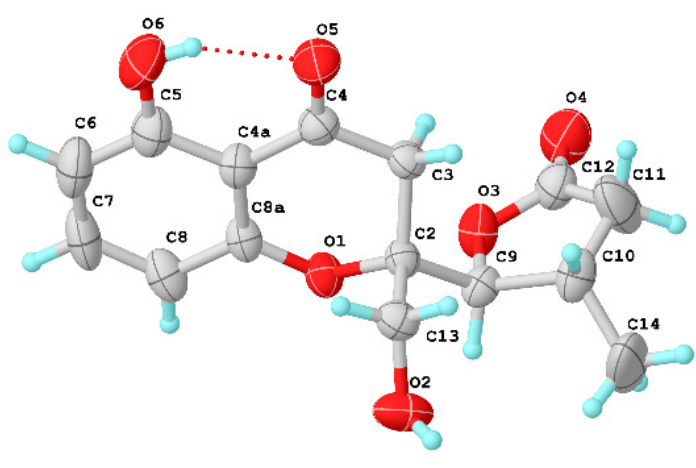

1

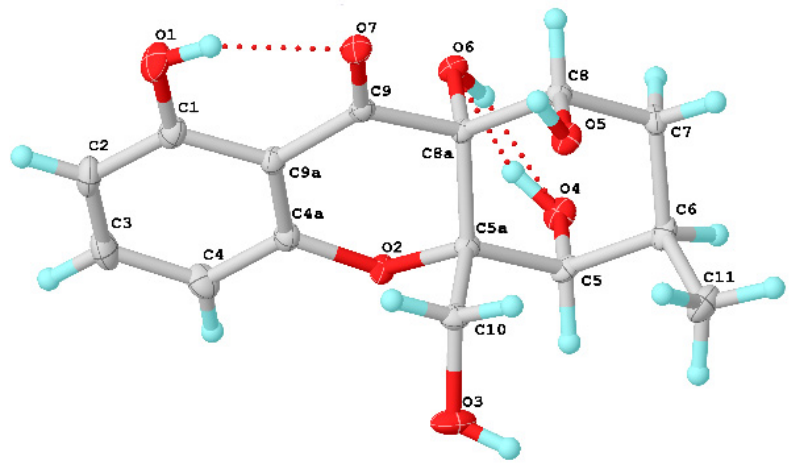

2

Figure 4. X-ray crystallographic analysis of $\mathbf{1}$ and $\mathbf{2}$.

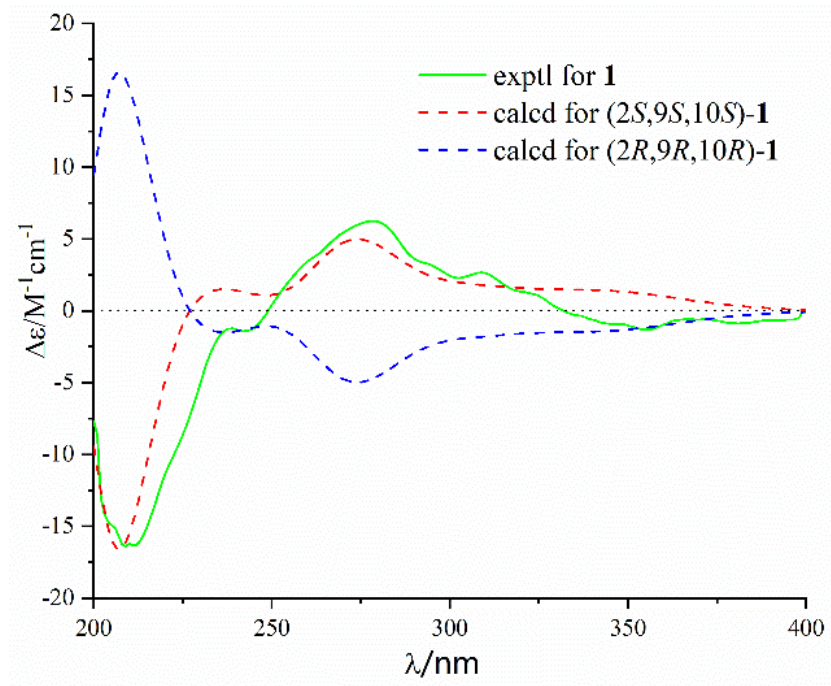

(a)

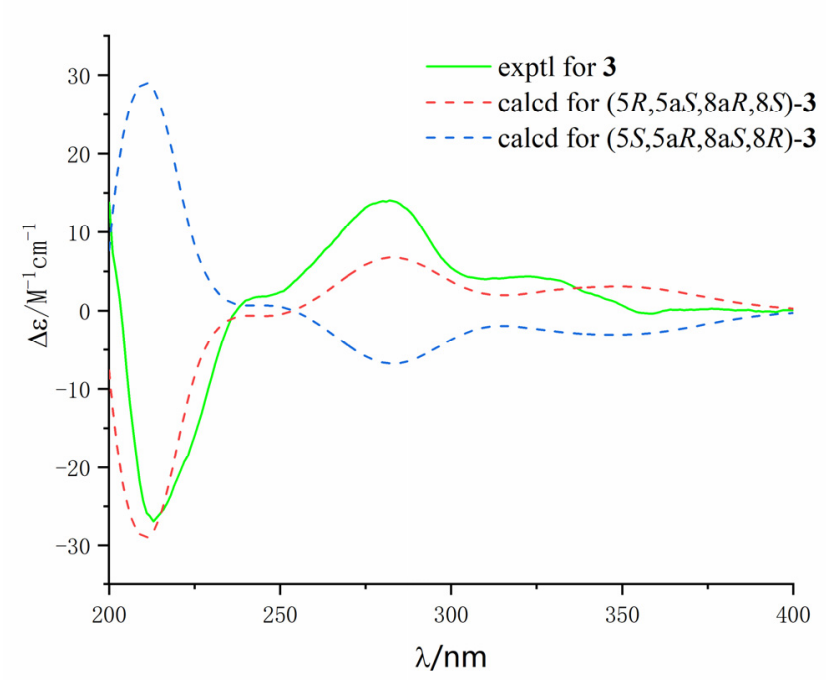

(b)

Figure 5. Experimental and predicted ECD spectra of $\mathbf{1}(\mathbf{a})$ and $\mathbf{3}(\mathbf{b})$ in $\mathrm{MeOH}$.

It can be seen that the proton $\mathrm{H}_{2}-3$ of $\mathbf{1}$ was the $\alpha-\mathrm{H}$ atom of ketone with weak acid, whose $\alpha$-hydrogen exchange ( $\alpha$-deuterodeprotonatioion reaction) could be found in $\mathrm{CD}_{3} \mathrm{OD}$. The signal of $\mathrm{H}_{2}-3$ was observed as a weak and small peak, and the integrals were 
much less than two in the ${ }^{1} \mathrm{H}$ NMR spectrum. The natural product with the $\alpha-\mathrm{H}$ atom of ketone moiety would be better for acquiring the NMR data under the deuterated solvents without exchangeable deuterium.

Diaporthone B (2) was obtained as yellow crystal, and its molecular formula was established as $\mathrm{C}_{15} \mathrm{H}_{18} \mathrm{O}_{7}$ by the negative HRESIMS ions at $m / z 309.0976[\mathrm{M}-\mathrm{H}]^{-}$(calculated for $\mathrm{C}_{15} \mathrm{H}_{17} \mathrm{O}_{7}, 309.0980$ ), indicating eight degrees of unsaturation. The ${ }^{1} \mathrm{H}$ NMR (Figure S10) displayed three aromatic protons $\left(\delta_{\mathrm{H}} 6.44(1 \mathrm{H}, \mathrm{dd}, J=8.2,0.9 \mathrm{~Hz}) ; 6.55(\mathrm{H}, \mathrm{d}, J=8.2 \mathrm{~Hz})\right.$; $7.39(1 \mathrm{H}, \mathrm{t}, J=8.3 \mathrm{~Hz}))$, three methines $\left(\delta_{\mathrm{H}} 4.44(1 \mathrm{H}, \mathrm{t}, J=4.2 \mathrm{~Hz}) ; 4.29(1 \mathrm{H}, \mathrm{m}) ; 2.34(1 \mathrm{H}, \mathrm{m})\right)$, two methylenes $\left(\delta_{\mathrm{H}} 1.57(1 \mathrm{H}, \mathrm{dd}, J=14.5,2.8 \mathrm{~Hz}), 2.43(1 \mathrm{H}, \mathrm{m}) ; 3.83(1 \mathrm{H}, \mathrm{d}, J=13.5 \mathrm{~Hz}), 4.28\right.$ $(1 \mathrm{H}, \mathrm{s}))$, and one methyl $\left(\delta_{\mathrm{H}} 1.32(3 \mathrm{H}, \mathrm{d}, J=7.8 \mathrm{~Hz})\right)$. The ${ }^{13} \mathrm{C}$ NMR showed the presence of 15 carbons corresponding to seven $\mathrm{sp}^{2}$ hybrid carbons including one ketone carbonyl $\left(\delta_{\mathrm{C}} 196.4\right)$ for xanthone characteristic and eight $\mathrm{sp}^{3}$ hybrid carbons. The planar structure of 2 was identified by ${ }^{1} \mathrm{H}-{ }^{1} \mathrm{H}$ COSY, HSQC, and HMBC spectroscopic data (Figure 2). The HMBC correlations from $\mathrm{H}-10$ to $\mathrm{C}-5 \mathrm{a}$ and $\mathrm{C}-8 \mathrm{a}$, from $\mathrm{H}-3$ to $\mathrm{C}-1$ and $\mathrm{C}-4 \mathrm{a}$, and ${ }^{1} \mathrm{H}-{ }^{1} \mathrm{H}$ COSY of $\mathrm{H}-2 / \mathrm{H}-3 / \mathrm{H}-4$, as well as the NMR chemical shifts, suggested the presence of a hydroxylchromone skeleton with a hydroxymethyl group at C-5a and a hydroxyl at C-8a. The remaining ring was assigned to be 4-hydroxyl-5-methyl cyclohexenol on the basis of ${ }^{1} \mathrm{H}-{ }^{1} \mathrm{H}$ COSY of H-6/H-7/H-8/H-9 and H-6/H-11, and key HMBC correlations from $\mathrm{H}-8$ to C-9 and C-5a, H-5 to C-8a. Finally, the structure and absolute configuration $(5 S, 5 \mathrm{a} S, 6 R$, $8 \mathrm{a} R, 8 S$ ) were distinctly demonstrated by X-ray crystallographic analysis (Figure 4) from $\mathrm{Cu} \mathrm{K} \alpha$ data with a Flack parameter of -0.01(14) [17] and a Hooft parameter of 0.06(7) [18].

Diaporthone C (3) was obtained as a colorless oil, whose molecular formula was determined as $\mathrm{C}_{15} \mathrm{H}_{16} \mathrm{O}_{7}$ on the basis of negative-ion HRESIMS $\left(\mathrm{m} / z 307.0820\left[\mathrm{M}-\mathrm{H}^{-}\right.\right.$, calculated for $\mathrm{C}_{15} \mathrm{H}_{15} \mathrm{O}_{7}, 307.0823$ ). Detailed analysis of its NMR spectroscopic data (Table 2) suggested that 3 was similar to 2 belonging to the xanthone class, except for the presence of an additional double bond $\left(\delta_{\mathrm{C}} 140.1\right.$ and $\left.122.1 ; \delta_{\mathrm{H}} 5.60\right)$ in 3 . The key HMBC correlations from methyl protons $\mathrm{H}-11$ to olefinic carbons C-6 and C-7 were allowed to assign the location of the double bond in 3 . The gross structure of 3 was identified by the 2D NMR spectroscopy (Figure 2). NOE correlations of $\mathrm{H}-5$ with $\mathrm{H}-10$ and $\mathrm{H}-10$ with $\mathrm{H}-8$ were not observed, and the relative configuration of compound 3 should be $5 R^{*}, 5 \mathrm{a} S^{*}, 8 \mathrm{a} R^{*}$, and $8 S^{*}$ (Figure 3). The predicted ECD curve of 3 matched well with the experimental one (Figure 5). Hence, the absolute configuration of 3 was identified as $5 R, 5 \mathrm{a} S, 8 \mathrm{a} R$, and $8 S$.

Diaporthone $\mathrm{D}(4)$ was obtained as a colorless oil, and its molecular formula $\mathrm{C}_{15} \mathrm{H}_{19} \mathrm{O}_{6}$ was identified by the positive HRESIMS ion at HRESIMS $m / z 295.1169[\mathrm{M}+\mathrm{H}]^{+}$(calculated $^{-}$ for $\mathrm{C}_{15} \mathrm{H}_{19} \mathrm{O}_{6}$, 295.1176). Comparison of the ${ }^{1} \mathrm{H}$ and ${ }^{13} \mathrm{C}$ NMR data (Table 1) of 4 with those of $\mathbf{2}$ suggested that 4 possessed the same xanthone framework, except for one of the hydroxyl groups $(8 \mathrm{a}-\mathrm{OH})$ in 2 being replaced by a proton in 4 . The ${ }^{1} \mathrm{H}-{ }^{1} \mathrm{H}$ COSY of $\mathrm{H}-8$ and $\mathrm{H}-8 \mathrm{a}$ and $\mathrm{HMBC}$ correlations from $\mathrm{H}-8 \mathrm{a}$ to $\mathrm{C}-9$ and $\mathrm{C}-10$ assigned the position of the proton $\mathrm{H}-8$, in accordance with the proton having double peaks at $2.48 \mathrm{ppm}$ (Figures S26-S31). The gross structure of 4 was identified by the 2D NMR spectroscopy (Figure 2). The coupling constant value of $J_{8,8 \mathrm{a}}=4.5 \mathrm{~Hz}$ and $\mathrm{NOE}$ correlation of $\mathrm{H}-8 \mathrm{a}$ with $\mathrm{H}-8$ indicated that the orientation of H-8 and H-8a was the same face of cyclohexane (Figure 3). The coupling constant value of $J_{5,6}=2.1 \mathrm{~Hz}$ and NOE correlation of $\mathrm{H}-5$ with $\mathrm{H}-6$ and $\mathrm{H}-10$ suggested that H-5, H-6, and H-10 were on the same side. The relative configuration of compound 4 was assigned as $5 R^{*}, 5 \mathrm{a} R^{*}, 6 R^{*}, 8 \mathrm{a} R^{*}$, and $8 R^{*}$. The absolute configuration of 4 was assigned by comparing the experimental and calculated ECD spectra, and the calculated ECD spectrum was agreed with that of the experimental one (Figure 6). Therefore, the absolute configuration of 4 was assigned as $5 R, 5 \mathrm{a} R, 6 R, 8 \mathrm{a} R$, and $8 R$. 
Table 2. ${ }^{1} \mathrm{H}(400 \mathrm{MHz})$ and ${ }^{13} \mathrm{C}(100 \mathrm{MHz}) \mathrm{NMR}$ spectroscopic data of $\mathbf{2}-\mathbf{4}$.

\begin{tabular}{|c|c|c|c|c|c|c|}
\hline \multirow[b]{2}{*}{ No. } & \multicolumn{2}{|c|}{$2^{a}$} & \multicolumn{2}{|r|}{$3^{b}$} & \multicolumn{2}{|c|}{$4^{a}$} \\
\hline & $\delta_{\mathrm{C}}$, Type & $\begin{array}{l}\delta_{\mathrm{H}}, \text { Mult } \\
(J \text { in } \mathrm{Hz})\end{array}$ & $\delta_{\mathrm{C}}$, Type & $\delta_{\mathrm{H}}$, Mult $(J$ in $\mathrm{Hz})$ & $\delta_{\mathrm{C}}$, Type & $\begin{array}{l}\delta_{\mathrm{H}}, \text { Mult } \\
(J \text { in } \mathrm{Hz})\end{array}$ \\
\hline 1 & $163.4, \mathrm{C}$ & & $163.1, \mathrm{C}$ & & $162.5, \mathrm{C}$ & \\
\hline 2 & $109.7, \mathrm{CH}$ & $6.44, \mathrm{dd}(8.2,0.9)$ & $108.8, \mathrm{CH}$ & $6.36, \mathrm{~d}(8.7)$ & $109.2, \mathrm{CH}$ & 6.41, dd $(8.3,1.0)$ \\
\hline 3 & $139.0, \mathrm{CH}$ & $7.39, \mathrm{t}(8.3)$ & $138.6, \mathrm{CH}$ & $7.36, \mathrm{t}(8.3)$ & $138.8, \mathrm{CH}$ & $7.34, \mathrm{t}(8.3)$ \\
\hline 4 & 109.6, CH & $6.55, \mathrm{~d}(8.2)$ & 108.2, $\mathrm{CH}$ & $6.39, \mathrm{~d}(8.8)$ & $109.2, \mathrm{CH}$ & 6.41, dd $(8.3,1.0)$ \\
\hline $4 a$ & $159.8, \mathrm{C}$ & & $160.9, \mathrm{C}$ & & 161.1, C & \\
\hline 5 & $75.3, \mathrm{CH}$ & $4.29, \mathrm{~m}$ & $73.9, \mathrm{CH}$ & $4.74, \mathrm{~d}(6.3)$ & $71.6, \mathrm{CH}$ & $3.90, \mathrm{~d}(2.1)$ \\
\hline $5 a$ & $76.2, \mathrm{C}$ & & $74.3, \mathrm{C}$ & & $83.5, \mathrm{C}$ & \\
\hline 6 & $36.2, \mathrm{CH}$ & $2.34, \mathrm{~m}$ & $140.1, \mathrm{C}$ & & $26.4, \mathrm{CH}$ & $2.43, \mathrm{~m}$ \\
\hline 7 & $29.9, \mathrm{CH}_{2}$ & $\begin{array}{c}\text { 1.57, } \mathrm{dt}(14.8,2.8) \\
2.43, \mathrm{~m}\end{array}$ & 122.1, CH & $5.60, \mathrm{dt}(4.6,1.8)$ & $34.9, \mathrm{CH}_{2}$ & $\begin{array}{l}1.53, \mathrm{~m} \\
1.84, \mathrm{~m}\end{array}$ \\
\hline 8 & $69.6, \mathrm{CH}$ & $4.44, \mathrm{t}(3.6)$ & $68.0, \mathrm{CH}$ & $4.61, \mathrm{t}(5.0)$ & $69.4, \mathrm{CH}$ & $4.23, \mathrm{dt}(4.7,2.6)$ \\
\hline $8 a$ & $85.0, \mathrm{C}$ & & $86.9, \mathrm{C}$ & & $48.5, \mathrm{CH}$ & $2.48, \mathrm{~d}(4.5)$ \\
\hline 9 & $196.4, \mathrm{C}$ & & 197.3, C & & $202.4, \mathrm{C}$ & \\
\hline $9 a$ & $108.6, \mathrm{C}$ & & $108.3, \mathrm{C}$ & & $111.3, \mathrm{C}$ & \\
\hline 10 & $60.5, \mathrm{CH}_{2}$ & $\begin{array}{c}3.83, \mathrm{~d}(13.5) \\
4.28, \mathrm{~m}\end{array}$ & 64.3, $\mathrm{CH}_{2}$ & $4.09, \mathrm{~m}$ & $63.2, \mathrm{CH}_{2}$ & $\begin{array}{l}3.72, \mathrm{~d}(12.0) \\
3.81, \mathrm{~d}(12.0)\end{array}$ \\
\hline 11 & 20.7, $\mathrm{CH}_{3}$ & $1.32, \mathrm{~d}(7.8)$ & $19.3, \mathrm{CH}_{3}$ & $1.84, \mathrm{~d}(1.4)$ & $18.0, \mathrm{CH}_{3}$ & $1.06, \mathrm{~d}(7.0)$ \\
\hline $1-\mathrm{OH}$ & & & & $11.26, \mathrm{~s}$ & & \\
\hline $5-\mathrm{OH}$ & & & & $4.84, \mathrm{~d}(6.6)$ & & \\
\hline $8-\mathrm{OH}$ & & & & $4.69, \mathrm{~d}(5.1)$ & & \\
\hline $8 \mathrm{a}-\mathrm{OH}$ & & & & $5.43, \mathrm{~s}$ & & \\
\hline $10-\mathrm{OH}$ & & & & $3.80, \mathrm{~d}(5.1)$ & & \\
\hline
\end{tabular}

${ }^{\text {a }}$ Spectra were recorded in $\mathrm{CD}_{3} \mathrm{OD} ;{ }^{\mathrm{b}}$ Spectra were recorded in acetone- $d_{6}$.

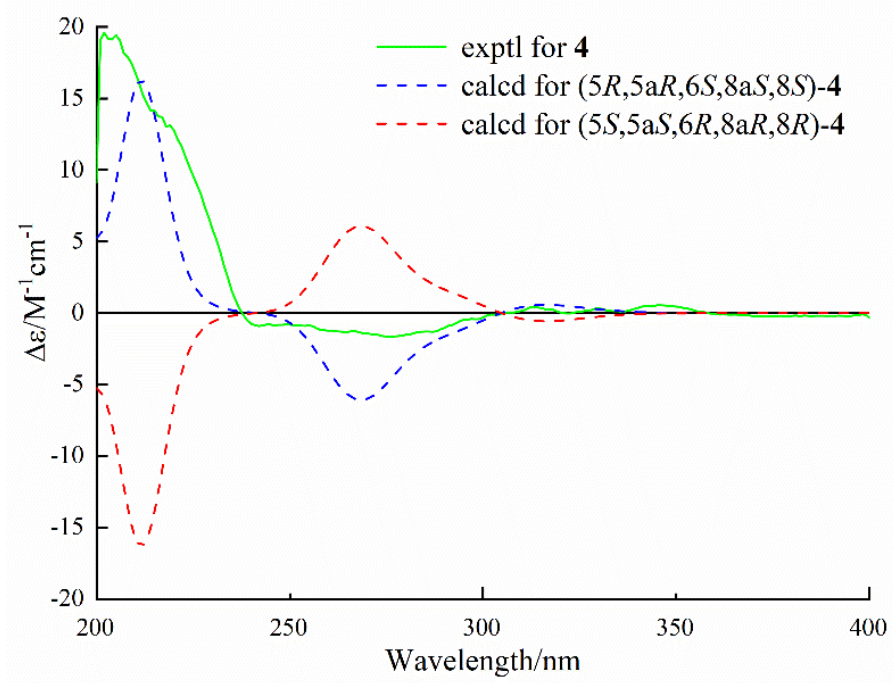

(a)

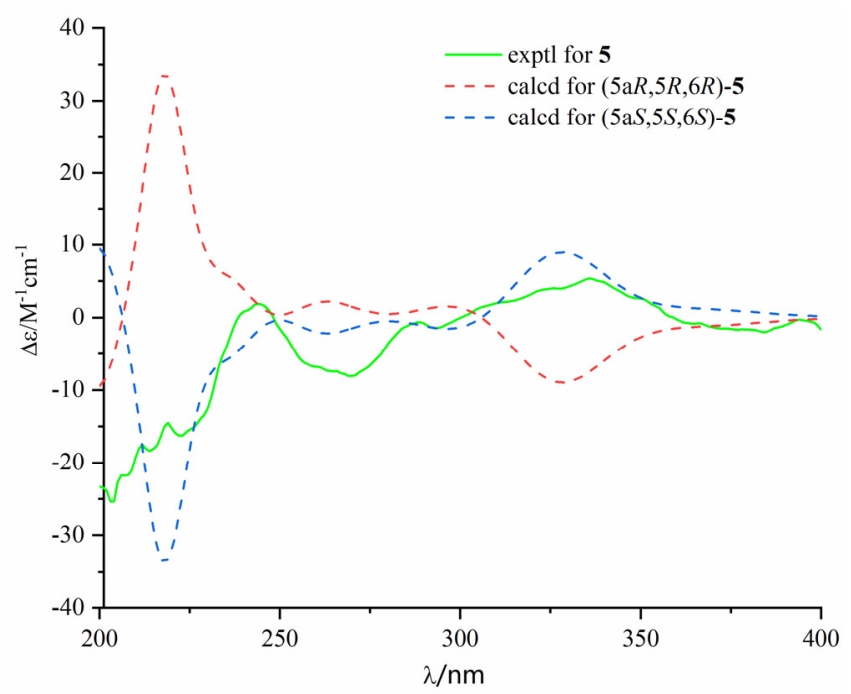

(b)

Figure 6. Experimental and predicted ECD spectra of 4 (a) and $5(\mathbf{b})$ in $\mathrm{MeOH}$.

Diaporthone E (5) was obtained as a colorless oil. The negative HRESIMS $m / z 333.0975$ $[\mathrm{M}-\mathrm{H}]^{-}$(calculated for $\mathrm{C}_{17} \mathrm{H}_{17} \mathrm{O}_{7}, 333.0980$ ) suggested the molecular formula of 5 was $\mathrm{C}_{17} \mathrm{H}_{18} \mathrm{O}_{7}$ with four degrees of unsaturation. The 1D and 2D NMR data (Figures S34-S39) indicated that compound 5 shared the same xanthone skeleton as penexanthone B (9). The only difference between them was that compound 5 was the absence of an additional acetyl group (10-Ac) compared to 6 . Compound 5 was a precursor of biosynthesis of 12-deacetylphomoxanthone A (15), and there is reason to believe that they share the same absolute configuration of $5 S, 5 \mathrm{a} S$, and $6 S$. The predicted ECD spectrum of $(5 S, 5 \mathrm{a} S, 6 S)-5$ 
showed well fit with that of the experimental one (Figure 6). Thus, compound 5 was identified as de-10-acetylpenexanthone B.

Diaporthone F (6) was obtained as a yellow crystal and had the same molecular formula $\left(\mathrm{C}_{15} \mathrm{H}_{16} \mathrm{O}_{7}\right)$ as 8 established by the HR-ESIMS ions at $m / z 307.0828[\mathrm{M}-\mathrm{H}]^{-}$ (calculated for $\mathrm{C}_{15} \mathrm{H}_{15} \mathrm{O}_{7}, 307.0823$ ). Compound $\mathbf{6}$ shared the same planar structure as phomoxanthone $\mathrm{G}(8)$, which was further identified by ${ }^{1} \mathrm{H}_{-}{ }^{1} \mathrm{H}$ COSY, HSQC, and HMBC spectroscopies (Figures S42-S47). Detailed analysis of their NMR (Table 3), diaporthone F (6) and phomoxanthone G should be a pair of epimers. The structure of 6 (Figure 7) and configuration $(5 R, 5 a R, 6 S, 8 a S, 8 R)$ were identified by X-ray crystallographic analysis from $\mathrm{Cu} \mathrm{K} \alpha$ data with a Flack parameter of -0.13(15) [17] and a Hooft parameter of 0.16(9).

Table 3. ${ }^{1} \mathrm{H}(400 \mathrm{MHz})$ and ${ }^{13} \mathrm{C}(100 \mathrm{MHz}) \mathrm{NMR}$ spectroscopic data of 5-7.

\begin{tabular}{|c|c|c|c|c|c|c|}
\hline \multirow[b]{2}{*}{ No. } & \multicolumn{2}{|r|}{$5^{a}$} & \multicolumn{2}{|r|}{$6^{a}$} & \multicolumn{2}{|r|}{$7^{b}$} \\
\hline & $\delta_{\mathrm{C}}$, Type & $\delta_{\mathrm{H}}$, Mult $(J$ in Hz) & $\delta_{\mathrm{C}}$, Type & $\delta_{\mathrm{H}}$, Mult $(J$ in $\mathrm{Hz})$ & $\delta_{\mathrm{C}}$, type & $\delta_{\mathrm{H}}$, Mult $(J$ in $\mathrm{Hz})$ \\
\hline 1 & 162.0, C & & $164.4, \mathrm{C}$ & & $163.4, \mathrm{C}$ & \\
\hline 2 & $108.1, \mathrm{CH}$ & $6.42, \mathrm{~d}(8.2)$ & $108.5, \mathrm{CH}$ & $6.52, \mathrm{~d}(8.2)$ & $109.7, \mathrm{CH}$ & $6.48, \mathrm{dd},(8.3,0.9)$ \\
\hline 3 & $138.2, \mathrm{CH}$ & $7.31, \mathrm{t}(8.3)$ & 139.0, $\mathrm{CH}$ & $7.45, \mathrm{t}(8.3)$ & $139.0, \mathrm{CH}$ & $7.43, \mathrm{t},(8.3)$ \\
\hline 4 & $110.5, \mathrm{CH}$ & $6.52, \mathrm{~d}(8.3)$ & $110.9, \mathrm{CH}$ & $6.54, \mathrm{~d}(8.2)$ & 109.7, CH & $6.59, \mathrm{dd},(8.3,0.9)$ \\
\hline $4 a$ & 157.6, C & & $161.2, \mathrm{C}$ & & $160.2, \mathrm{C}$ & \\
\hline 5 & $70.3, \mathrm{CH}$ & $5.72, \mathrm{~s}$ & $80.5, \mathrm{CH}$ & $4.22, \mathrm{~s}$ & $74.5, \mathrm{CH}$ & $4.28, \mathrm{~m}$ \\
\hline $5 a$ & $82.4, \mathrm{C}$ & & $78.1, \mathrm{C}$ & & $76.3, \mathrm{C}$ & \\
\hline 6 & $27.8, \mathrm{CH}$ & $2.39, \mathrm{~m}$ & $82.9, \mathrm{C}$ & & $29.2, \mathrm{CH}$ & $2.25, \mathrm{~m}$ \\
\hline 7 & $33.5, \mathrm{CH}_{2}$ & $2.43, \mathrm{~m}$ & 36.9, $\mathrm{CH}_{2}$ & $\begin{array}{c}1.80, \mathrm{dt}(15.2, \\
0.8) 2.39, \mathrm{dd}(15.2 \\
5.4)\end{array}$ & $31.9, \mathrm{CH}_{2}$ & $2.25, \mathrm{~m} 2.06, \mathrm{~m}$ \\
\hline 8 & $178.1, \mathrm{C}$ & & $71.1, \mathrm{CH}$ & $4.47, \mathrm{dd}(5.3,0.9)$ & $68.5, \mathrm{CH}$ & $4.40, \mathrm{t},(2.9)$ \\
\hline $8 a$ & 101.0, C & & $81.9, \mathrm{C}$ & & $85.4, \mathrm{C}$ & \\
\hline 9 & 187.7, C & & $195.6, \mathrm{C}$ & & 196.2, C & \\
\hline $9 a$ & 106.7, C & $3.51, \mathrm{~d}(13.2)$ & 107.5, C & & 108.6, C & \\
\hline 10 & $65.6, \mathrm{CH}_{2}$ & $4.03, \mathrm{~d}(13.2)$ & $67.9, \mathrm{CH}_{2}$ & $\begin{array}{c}4.38, \mathrm{~d}(8.1) 3.65, \mathrm{~d} \\
(8.1)\end{array}$ & $60.4, \mathrm{CH}_{2}$ & $\begin{array}{c}4.26, \mathrm{~d}(13.4) 3.78, \mathrm{~d} \\
(13.4)\end{array}$ \\
\hline 11 & $17.7, \mathrm{CH}_{3}$ & $1.06, \mathrm{~d}(5.5)$ & $23.9, \mathrm{CH}_{3}$ & $1.33, \mathrm{~s}$ & $18.1, \mathrm{CH}_{3}$ & $1.12, \mathrm{~d}(6.7)$ \\
\hline 12 & $170.8, \mathrm{C}$ & & & & & \\
\hline 13 & 21.0, $\mathrm{CH}_{3}$ & $2.09, \mathrm{~s}$ & & & & \\
\hline 14 & $162.0, \mathrm{C}$ & & & & & \\
\hline
\end{tabular}

a Spectra were recorded in $\mathrm{CDCl}_{3} ;{ }^{\mathrm{b}}$ Spectra were recorded in $\mathrm{CD}_{3} \mathrm{OD}$.

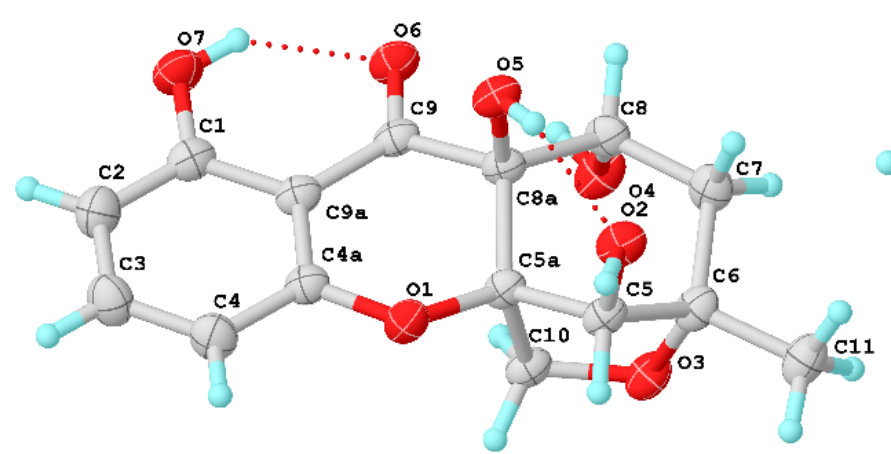

6

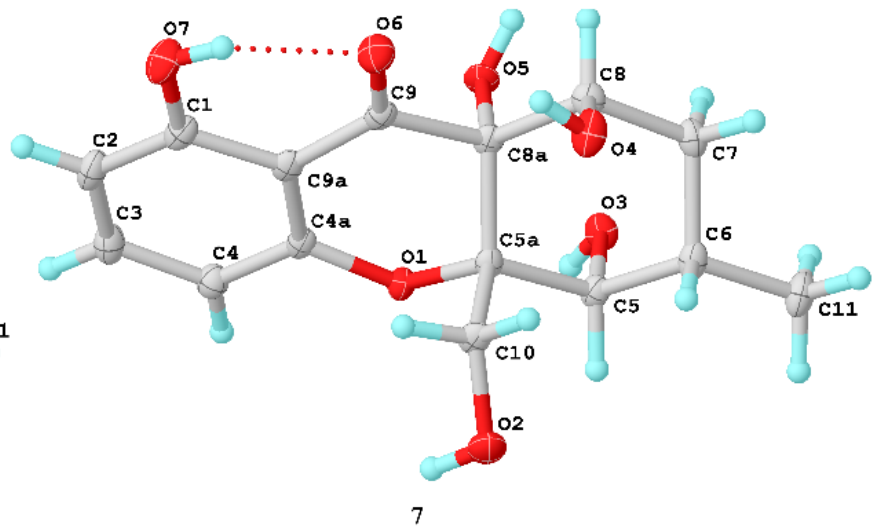

7

Figure 7. X-ray crystallographic analysis of 6 and 7.

Compounds 7 was obtained as a yellow crystal and had the molecular formula $\mathrm{C}_{15} \mathrm{H}_{18} \mathrm{O}_{7}$, which was established by the HR-ESIMS ions at $m / z 309.0978[\mathrm{M}-\mathrm{H}]^{-}$ (calculated for $\mathrm{C}_{15} \mathrm{H}_{17} \mathrm{O}_{7}, 309.0979$ ). The structure of 7 was clearly identified by X-ray crystallographic analysis (Figure 6), whose relative and planar structure was the same as 
that of phaseolorin D [19]. In detail, the X-ray structure was the monoclinic space group $P 2_{1} / \mathrm{c}$ (Figure 7), which was different from that of phaseolorin D ((+)-7) with the triclinic space group. It suggested that compound 7 should be an enantiomer in the solid crystals (Figure 8), which showed an excellent fit with the result of no signal of CD spectrum and no optical activity sign in methanol. Subsequently, the chiral HPLC was used for purification of $( \pm)-7$, and the two enantiomers, $(+)-7\left(t_{\mathrm{R}}=28.7 \mathrm{~min}\right)$ and $(-)-7\left(t_{\mathrm{R}}=31.5 \mathrm{~min}\right)$ were purified, respectively, and showed opposite Cotton effects in their $\mathrm{CD}$ spectra and opposite optical rotations (Figure 9). The calculated ECD curve of $(5 R, 5 \mathrm{a} R, 6 R, 8 \mathrm{a} S, 8 R)-7$ was comparable to the experimental one of (-)-7, resulting in that the absolute configuration of $(-)-7$ was $5 R, 5 a R, 6 R, 8 a S, 8 R$. Compounds 2 and $( \pm)-7$ were epimers derived from the same precursor, chrysophanol, and a possible biogenetic pathway for 2 and $( \pm)-7$ was proposed, as shown in Figure S62 (supplementary mateial). Compounds 2, 3, and (+)-7 showed a very similar ECD spectrum with a strong and negative Cotton effect (CE) at 209 $\mathrm{nm}$ and two negative CEs at approximately 281 and $326 \mathrm{~nm}$ (Figure S63, Supplementary Material), while (-)-7 revealed opposite Cotton effects. The negative Cotton effect (CE) at $209 \mathrm{~nm}$ should be derived from the $\mathrm{n}-\pi^{*}$ transition of the chromone chromophore with the absolute configuration of $5 \mathrm{a} S$ and $8 \mathrm{a} R$.

The other known compounds were identified as phaseolorin D (+)-(7) [19], Phomoxanthone G (8) [20], penexanthone B (9) [21], phaseolorin E (10) [19], phomoxanthone F (11) [20], penimethavone A(12) [22], monodictyxanthone (13) [23], methyl 6,8-dihydroxy-3methyl-9-oxo-9H-xanthene-1-carboxylate (14) [24], 12-deacetylphomoxanthone A (15) [25], phomoxanthone A (16) [26], dicerandrol B (17) [27], dicerandrol C (18) [27], phomoxanthone B (19) [26] and deacetylphomoxanthone B (20) [28] by comparing their spectroscopic data with those reported in the literature.

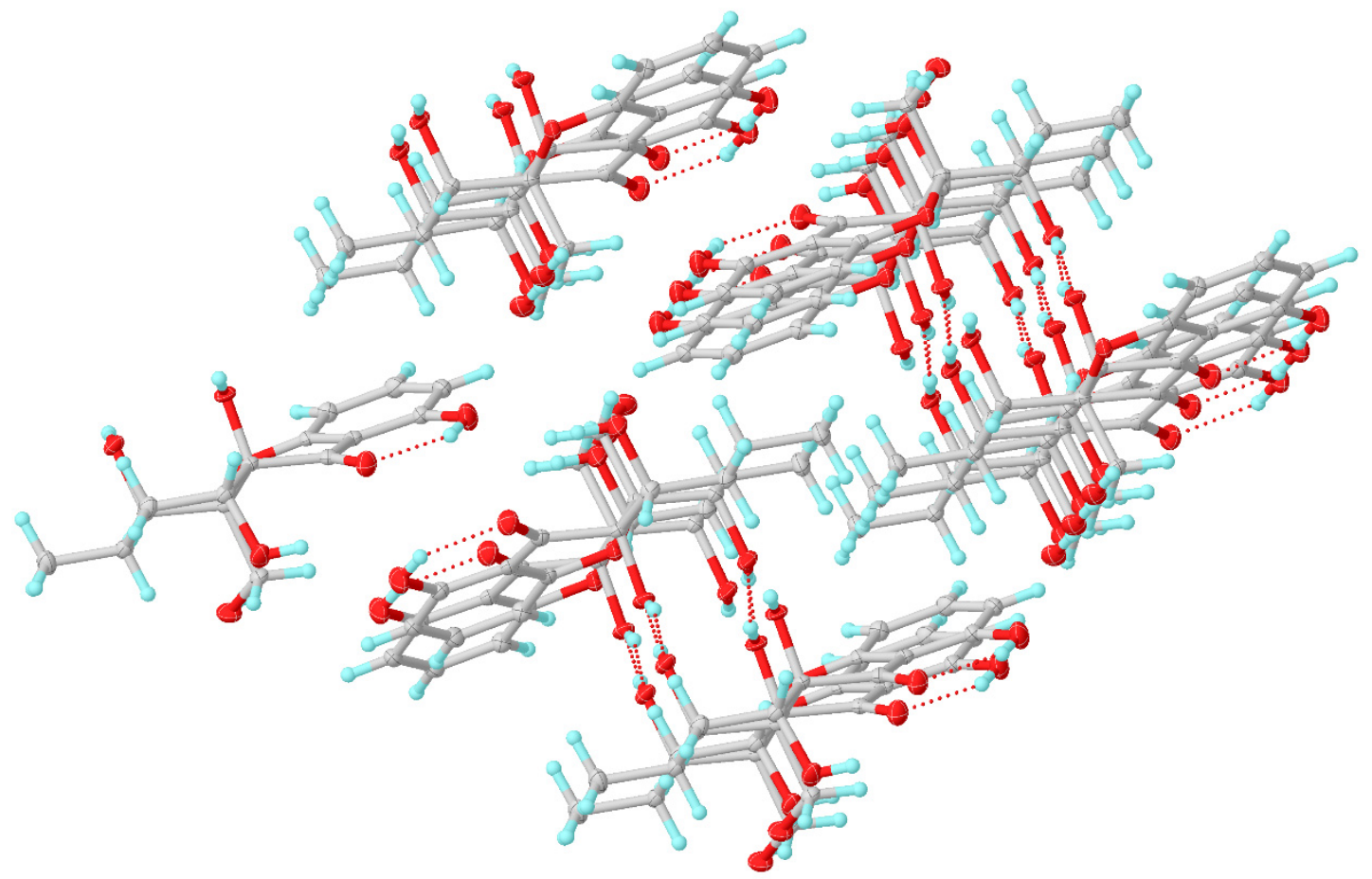

Figure 8. Molecular packing properties of 7. 


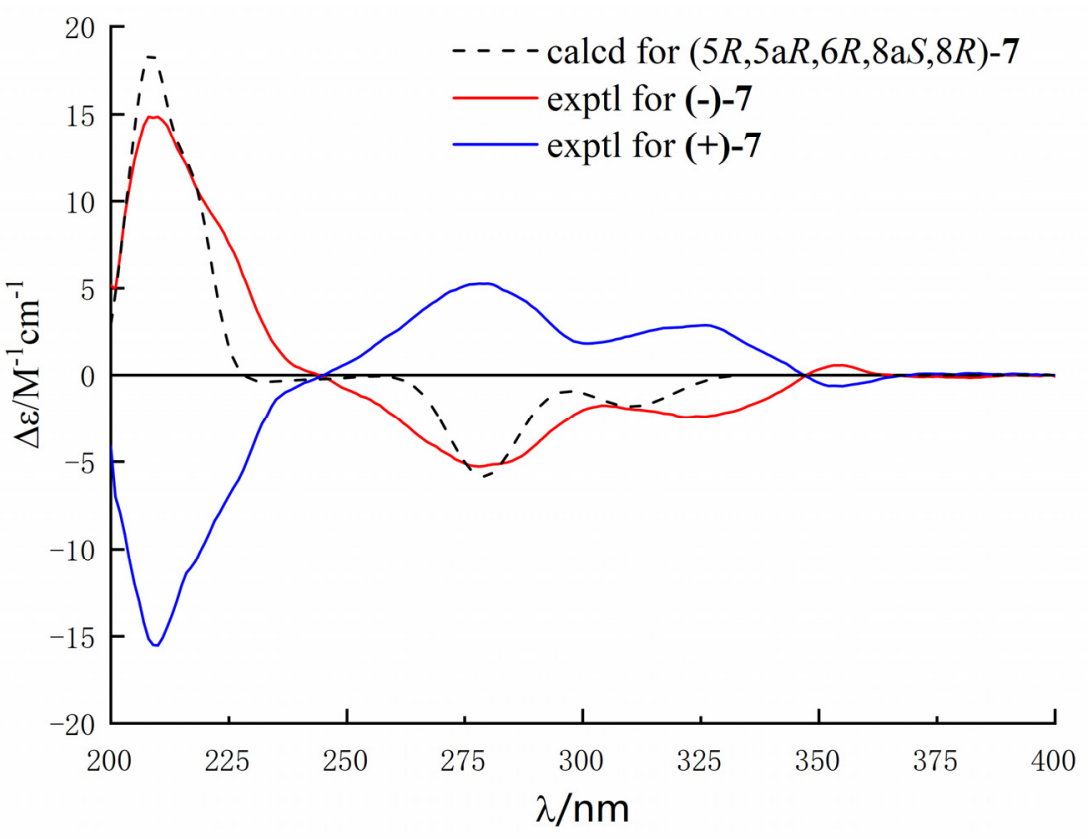

Figure 9. Experimental and predicted ECD spectra of (+)- and (-)-7 (in $\mathrm{MeOH})$.

All isolates were evaluated for anti-glioma using T98G, U87MG, and U251 human cell lines with temozolomide as the positive control. Only dimeric xanthones (15-20) exhibited promising growth-inhibitory effects on the T98G cell line with $\mathrm{IC}_{50}$ values between 19.5 to $78.0 \mu \mathrm{M}$ (Table 4). Additionally, all monomeric xanthones (1-14) displayed weak or no cytotoxicity against T98G, U87MG, and U251 human cell lines. The result suggested that the dimeric skeleton of xanthones played an important role in anti-glioma activity.

Table 4. Anti-glioma activity against T98G, U87MG, and U251 human cell lines and inhibition of NO production in LPS-induced RAW264.7 cells of compounds 11 and 14-20.

\begin{tabular}{|c|c|c|c|c|}
\hline Compounds & $\begin{array}{c}\text { T98G }\left(\mathrm{IC}_{50}\right. \\
\mu \mathrm{M})\end{array}$ & $\begin{array}{c}\text { U87MG }\left(\mathrm{IC}_{50}\right. \\
\mu \mathrm{M})\end{array}$ & $\begin{array}{l}\mathrm{U} 251\left(\mathrm{IC}_{50}\right. \\
\mu \mathrm{M})\end{array}$ & $\begin{array}{c}\text { Inhibition of NO } \\
\text { Production, } \mathrm{IC}_{50}(\mu \mathrm{M})\end{array}$ \\
\hline 11 & $>100$ & $>100$ & $>100$ & 41.4 \\
\hline 14 & $>100$ & $>100$ & $>100$ & 32.2 \\
\hline 15 & 23.8 & $>100$ & $>100$ & 6.3 \\
\hline 16 & 19.5 & $>100$ & $>100$ & 7.5 \\
\hline 17 & 57.6 & $>100$ & $>100$ & 6.3 \\
\hline 18 & 34.6 & $>100$ & $>100$ & 7.6 \\
\hline 19 & 74.1 & $>100$ & $>100$ & 8.0 \\
\hline 20 & 78.2 & $>100$ & $>100$ & 7.8 \\
\hline Temozolomide & 151 & 203 & 189 & - \\
\hline Indomethacin & - & - & - & 35.8 \\
\hline
\end{tabular}

All compounds $(\mathbf{1}-\mathbf{2 0})$ were also tested for the inhibition of nitric oxide (NO) production in RAW264.7 cells activated by lipopolysaccharide. Compounds 15-20 showed strong inhibition of $\mathrm{NO}$ with $\mathrm{IC}_{50}$ values between 6.3 and $8.0 \mu \mathrm{M}$, compared to the positive control indomethacin, whose $\mathrm{IC}_{50}$ value was $35.8 \mu \mathrm{M}$ (Table 4). Compounds 11 and 14 exhibited considerable anti-inflammatory activity with $\mathrm{IC}_{50}$ values of 41.4 and $32.2 \mu \mathrm{M}$, respectively. However, the other compounds do not have effects on anti-inflammatory activity $\left(\mathrm{IC}_{50}>50 \mu \mathrm{M}\right)$. 


\section{Materials and Methods}

\subsection{General Experimental Procedures}

Optical rotations were recorded on an MCP-200 polarimeter (Anton Paar, Graz, Austria) with $\mathrm{MeOH}$ as solvent at $25^{\circ} \mathrm{C}$. UV spectra were measured on a Blue Star A spectrophotometer. IR data were carried out on a Fourier transformation infrared spectrometer coupled with an EQUINOX 55 infrared microscope (Bruker, Rheinstetten, Germany). A Bruker Avance $400 \mathrm{MHz}$ spectrometer (Bruker, Karlsruhe, Germany) was used for 1D and 2D NMR spectra test with TMS as an internal standard. ESIMS and HRESIMS data were measured on an ACQUITY QDA (Waters Corporation, Milford, MA, USA) and an LTQOrbitrap LC-MS spectrometer (Thermo Corporation, Waltham, MA, USA), respectively. A Shimadzu Essentia LC-16 was used for HPLC preparative separations by a Welch-Ultimate XB-C18 column $(250 \times 21.2 \mathrm{~mm}, 5 \mu \mathrm{M}, 12 \mathrm{~nm}$, Welch Materials, Inc., Shanghai, China $)$ an ACE-5-C18-AR, ACE-5-CN-ES and ACE-C18-PFP column $(250 \times 10 \mathrm{~mm}, 5 \mu \mathrm{M}, 12 \mathrm{~nm}$, FLM Advanced Chromatography Technologies Ltd., Guangzhou, China). Column chromatography (CC) was performed on silica gel (200-300 mesh, Qingdao Marine Chemical Inc., Qingdao, China) and Sephadex LH-20 (Amersham Biosciences, Uppsala, Sweden).

\subsection{Fungal Material}

The experimental strain SYSU-MS4722 was isolated from the ascidian Styela plicata that was obtained by Professor Lan Liu from the Bay of Da'ao, Shenzhen City, Guangdong, Province, China, in April 2016. The standard protocol [29] was used for the isolation of fungus. The molecular biological protocol that included DNA amplification and sequencing of the ITS region was used for fungal identification. The sequence data of the fungal strain have been deposited at GenBank with accession no. OK623372. A BLAST search result suggested that the sequence was most similar (100\%) to the sequence of Diaporthe sp. NFIF-2-6 (compared to MW202988.1).

\subsection{Extraction and Isolation}

The strain Diaporthe sp. SYSU-MS4722 was fermented on a solid medium in a $1 \mathrm{~L}$ culture flask (containing $50 \mathrm{~g}$ of rice and $50 \mathrm{~mL}$ of $\mathrm{H}_{2} \mathrm{O}$ with $3 \%$ sea salt) with a total of 120 flasks incubating at room temperature for 30 days. The solid fermentation was extracted with $\mathrm{MeOH}$ four times to afford a crude extract, and then the crude was dissolved in $\mathrm{H}_{2} \mathrm{O}$ and continuously was extracted four times with EtOAc. The EtOAc extract (42 g) was subjected to a silica gel column eluting with gradient petroleum ether/EtOAc (from 8:2 to $0: 1)$ to obtain six fractions $(\mathrm{A}-\mathrm{F})$.

Fr.A was fractionated on a Sephadex LH-20 column with $\mathrm{MeOH} / \mathrm{CH}_{2} \mathrm{Cl}_{2}$ (50:50) to afford three fractions (Fr.A.1 to Fr.A.3). Fr.A.3 was further purified by RP-HPLC $\left(\mathrm{MeOH} / \mathrm{H}_{2} \mathrm{O}\right.$, 80:20 flow rate $2 \mathrm{~mL} / \mathrm{min}$, ACE-C18-PFP column $10 \times 250 \mathrm{~mm}, 5 \mu \mathrm{M})$ to give $5(5.0 \mathrm{mg})$ and $9(11.0 \mathrm{mg})$. Fr.B was fractionated on a Sephadex $\mathrm{LH}-20$ column with $\mathrm{CH}_{2} \mathrm{Cl}_{2} / \mathrm{MeOH}$ to provide four subfractions (Fr.B.1 to Fr.B.4). Fr.B.1 was further subjected to silica gel chromatography eluting with $\mathrm{CH}_{2} \mathrm{Cl}_{2} / \mathrm{MeOH}$ (99:1) to afford $\mathbf{1 1}(2.0 \mathrm{mg})$. Fr.B.2 was further purified by silica gel chromatography and RP-HPLC $\left(\mathrm{MeOH} / \mathrm{H}_{2} \mathrm{O}, 75: 25\right.$ flow rate $2 \mathrm{~mL} / \mathrm{min}$, ACE-C18-PFP column $10 \times 250 \mathrm{~mm}, 5 \mu \mathrm{M})$ to obtain $13(6.0 \mathrm{mg}), 16(2.0 \mathrm{mg})$, and $19(3.0 \mathrm{mg})$. Fr.B.3 was further fractionated on a silica gel column and RP-HPLC to give $18(14.0 \mathrm{mg})$ and $20(12.0 \mathrm{mg})$. Fr.B.4 was subjected to a silica gel column with $\mathrm{CH}_{2} \mathrm{Cl}_{2} / \mathrm{MeOH}(98: 2)$ and then purified by RP-HPLC with $\mathrm{MeOH} / \mathrm{H}_{2} \mathrm{O}$ (70:30) to give 1 (2 mg), 15 (5.0 mg), and 17 (7.0 mg). Fr.C was applied to a silica gel column eluting with $\mathrm{CH}_{2} \mathrm{Cl}_{2} / \mathrm{MeOH}$ (97:3) to afford five fractions (Fr.C.4.1 to Fr.C.4.5). Fr.C.4.2 was further purified by silica gel column to give $4(8.0 \mathrm{mg})$. Fr.C.4.4 was subjected to silica gel chromatography to afford $8(9.1 \mathrm{mg})$ and subfraction (Fr.C.4.4.2). Fr.C.4.4.2 was further purified by $\mathrm{RP}-\mathrm{HPLC}\left(\mathrm{MeOH} / \mathrm{H}_{2} \mathrm{O}, 65: 35\right.$ flow rate $2 \mathrm{~mL} / \mathrm{min}$, ACE-C18-PFP column $10 \times 250 \mathrm{~mm}$, $5 \mu \mathrm{M})$ to give $2\left(5.0 \mathrm{mg}, t_{\mathrm{R}}=11.2 \mathrm{~min}\right), 7\left(2.0 \mathrm{mg}, t_{\mathrm{R}}=12.1 \mathrm{~min}\right)$, and $10\left(11.0 \mathrm{mg}, t_{\mathrm{R}}=14.0\right)$. Fr.C.4.5 was further fractionated on a silica gel column and RP-HPLC to afford 3 (4.0 mg), mboxtextbf12 (10.0 mg), and 14 (9.0 mg). 
Compound 1: $\mathrm{C}_{15} \mathrm{H}_{16} \mathrm{O}_{6}$; Yellow crystal; [ $\left.\alpha\right] 20 \mathrm{D}$ (c 0.01, MeOH) +41.2; UV (MeOH) $\lambda_{\max }(\log \varepsilon) 270(3.91) \mathrm{nm} ; \mathrm{CD}(\mathrm{MeOH}) \lambda_{\max }(\Delta \varepsilon) 212(-2.66), 243$ (+1.49) nm; IR (neat) $v_{\max } 3458,2976,1786,1653,1468,1234,1065 \mathrm{~cm}^{-1}$; HR-ESIMS $m / z 291.0869$ [M - H] ${ }^{-}$ (calculated for $\mathrm{C}_{15} \mathrm{H}_{15} \mathrm{O}_{6}, 291.0874$ ).

Compound 2: $\mathrm{C}_{15} \mathrm{H}_{18} \mathrm{O}_{7}$; Colorless crystal; $[\alpha] 20 \mathrm{D}$ (c $\left.0.01, \mathrm{MeOH}\right)+38.6$; UV (MeOH) $\lambda_{\max }(\log \varepsilon) 208$ (4.10), 277 (3.85) nm; CD (MeOH) $\lambda_{\max }(\Delta \varepsilon) 209$ (-28.85), 281 (+10.75), 326 $(+6.41) \mathrm{nm}$; IR (neat) $v_{\max } 3446,2952,1633,1610,1456,1225,1028 \mathrm{~cm}^{-1}$; HR-ESIMS $\mathrm{m} / z$ 309.0976 [M - H] $]^{-}$(calculated for $\mathrm{C}_{15} \mathrm{H}_{17} \mathrm{O}_{7}, 309.0980$ ).

Compound 3: $\mathrm{C}_{15} \mathrm{H}_{16} \mathrm{O}_{7}$; Colorless crystal; $[\alpha] 20 \mathrm{D}(\mathrm{c} 0.02, \mathrm{MeOH})+32.4 ; \mathrm{UV}(\mathrm{MeOH})$ $\lambda_{\max }(\log \varepsilon) 205$ (4.03), $278(3.87) \mathrm{nm} ; \mathrm{CD}(\mathrm{MeOH}) \lambda_{\max }(\Delta \varepsilon) 212$ (-17.55), 282 (+9.36), 323 (+2.89) nm; IR (neat) $v_{\max } 3402,2962,1641,1583,1468,1213,1043 \mathrm{~cm}^{-1} ;$ HR-ESIMS $\mathrm{m} / z$ $307.0820[\mathrm{M}-\mathrm{H}]^{-}$(calculated for $\mathrm{C}_{15} \mathrm{H}_{15} \mathrm{O}_{7}, 307.0823$ ).

Compound 4: $\mathrm{C}_{15} \mathrm{H}_{18} \mathrm{O}_{6}$; Colorless powder; $[\alpha] 20 \mathrm{D}(\mathrm{c} 0.02, \mathrm{MeOH})+13.4 ; \mathrm{UV}(\mathrm{MeOH})$ $\lambda_{\max }(\log \varepsilon) 207$ (4.20), 276 (3.52) nm; CD (MeOH) $\lambda_{\max }(\Delta \varepsilon) 202$ (+24.71), 219 (+12.97) nm; IR (neat) $v_{\max } 3454,2970,1722,1643,1456,1363,1232,1045 \mathrm{~cm}^{-1} ;$ HR-ESIMS m/z 295.1169 $[\mathrm{M}+\mathrm{H}]^{+}$(calculated for $\mathrm{C}_{15} \mathrm{H}_{19} \mathrm{O}_{6}, 295.1176$ ).

Compound 5: $\mathrm{C}_{17} \mathrm{H}_{18} \mathrm{O}_{7}$; Colorless powder; $[\alpha] 20 \mathrm{D}$ (c 0.01, $\left.\mathrm{MeOH}\right)+9.2 ; \mathrm{UV}(\mathrm{MeOH})$ $\lambda_{\max }(\log \varepsilon) 224$ (3.75), 254(3.50) nm; CD (MeOH) $\lambda_{\max }(\Delta \varepsilon) 243(+0.44), 235$ (+1.32) nm; IR (neat) $v_{\max } 3438,2935,2871,1745,1616,1468,1238,1055 \mathrm{~cm}^{-1} ;$ HR-ESIMS $\mathrm{m} / z 333.0975$ $[\mathrm{M}-\mathrm{H}]^{-}$(calculated for $\mathrm{C}_{17} \mathrm{H}_{17} \mathrm{O}_{7}, 333.0980$ ).

Compound 6: $\mathrm{C}_{15} \mathrm{H}_{16} \mathrm{O}_{7}$; Colorless crystal; [ $\alpha$ ]20D (c 0.02, $\left.\mathrm{MeOH}\right)-175 ; \mathrm{UV}(\mathrm{MeOH})$ $\lambda_{\max }(\log \varepsilon) 208$ (4.05), 278(3.78), 356 (3.30) nm; IR (neat) $v_{\max } 3367,1630,1459,1222,1033$, $813 \mathrm{~cm}^{-1}$; HR-ESIMS $m / z$ 307.08278 [M - H] $]^{-}$(calculated for $\mathrm{C}_{15} \mathrm{H}_{15} \mathrm{O}_{7}, 307.08233$ ).

Compound 7: $\mathrm{C}_{15} \mathrm{H}_{18} \mathrm{O}_{7}$; Colorless crystal; UV (MeOH) $\lambda_{\max }(\log \varepsilon) 209$ (4.15), 279(3.78), 353 (3.30) nm; IR (neat) $v_{\max } 3499,3289,2936,1648,1629,1461,1224,1022$, 811, $694 \mathrm{~cm}^{-1}$; HR-ESIMS $m / z 309.0978[\mathrm{M}-\mathrm{H}]^{-}$(calculated for $\mathrm{C}_{15} \mathrm{H}_{19} \mathrm{O}_{7}, 309.0979$ ).

(+)-(7): $[\alpha] 20 \mathrm{D}(\mathrm{c} 0.0035, \mathrm{MeOH})+73.4 ; \mathrm{ECD}(\mathrm{MeOH}) \lambda_{\max }(\Delta \varepsilon): 209$ (-16.8), 279 $(+5.6), 327(+2.8) \mathrm{nm}$.

$(-)-(7):[\alpha] 20 \mathrm{D}($ c $0.0011, \mathrm{MeOH})-79.2 ; \mathrm{ECD}(\mathrm{MeOH}) \lambda_{\max }(\Delta \varepsilon): 209(+15.4), 279$ $(-5.1), 327(+2.5) \mathrm{nm}$.

\subsection{X-ray Crystallographic Analysis}

The crystals of compounds $\mathbf{1}, \mathbf{2}, \mathbf{6}$, and 7 were obtained on the base of the vapor diffusion method. All single-crystal X-ray diffraction data were collected on a Rigaku Oxford diffractometer with $\mathrm{Cu}-\mathrm{K} \alpha$ radiation $(\lambda=1.54178 \mathrm{~A})$. The structures were solved by direct methods using SHELXS-97 and refined full-matrix least-squares difference Fourier techniques using Olex2-1.2. All hydrogen atoms bonded to carbons were added at the geometrically ideal positions by the "ride on" method. All crystallographic data of 1, 2, 6, and 7 have been deposited with the Cambridge Crystallographic Data Centre. Copies of the data can be obtained, free of charge, on application to the Director, CCDC, 12 Union Road, Cambridge CB2 1EZ, UK (fax: 44-(0)1223-336033, or e-mail: deposit@ccdc.cam.ac.uk).

Compound 1: $\mathrm{C}_{15} \mathrm{H}_{16} \mathrm{O}_{6}(\mathrm{Mr}=291.09 \mathrm{~g} / \mathrm{mol})$, orthorhombic, space group $\mathrm{P} 2{ }_{1}{ }_{1} 2_{1}$, $a=5.4585(4) \AA, b=11.5804(10) \AA, c=22.0066(14) \AA, \alpha=90^{\circ}, \beta=90^{\circ}, \gamma=90^{\circ}, V=1391.07(18)$ $\AA^{3}, Z=4, T=249.99(10) \mathrm{K}, \mu(\mathrm{Cu} \mathrm{K} \alpha)=0.915 \mathrm{~mm}^{-1}, D_{\text {calc }}=1.3955 \mathrm{~g} / \mathrm{cm}^{3}, 5334$ reflections measured, 2742 unique $\left(R_{\text {int }}=0.0538, R_{\text {sigma }}=0.0628\right)$, which were used in all calculations. The final $R_{1}$ was $0.0557(I>=2 u(I))$ and $w R_{2}$ was 0.1503 . The Flack parameter was $0.0(3)$, and the Hooft parameter was -0.2(3). Goodness of fit on $\mathrm{F}^{2}$ was 1.048. CCDC 2116967.

Compound 2: $\mathrm{C}_{15} \mathrm{H}_{18} \mathrm{O}_{7}(\mathrm{Mr}=310.31 \mathrm{~g} / \mathrm{mol})$, monoclinic, space group $\mathrm{P}_{2}$, $a=10.1547(4) \AA, b=7.1459(2) \AA, c=10.3653(4) \AA, \alpha=90^{\circ}, \beta=116.414(4)^{\circ}, \gamma=90^{\circ}$, $V=673.63(5) \AA^{3}, Z=2$, Crystal size $0.35 \times 0.3 \times 0.25 \mathrm{~mm}^{3}, T=150.00(10) \mathrm{K}$, $\mu(\mathrm{Cu} \mathrm{K} \alpha)=1.036 \mathrm{~mm}^{-1}, D_{\text {calc }}=1.530 \mathrm{~g} / \mathrm{cm}^{3}, 4665$ reflections measured, 2621 unique $\left(R_{\text {int }}=0.0268, R_{\text {sigma }}=0.0298\right)$, which were used in all calculations. The final $R_{1}$ was $0.0359(\mathrm{I}>=2 u(I))$ and $w R_{2}$ was 0.0986 . The Flack parameter was $-0.01(14)$, and the Hooft parameter was 0.06(7). Goodness of fit on $\mathrm{F}^{2}$ was 1.044. CCDC 2116970. 
Compound 6: $\mathrm{C}_{15} \mathrm{H}_{16} \mathrm{O}_{7}(\mathrm{Mr}=308.29 \mathrm{~g} / \mathrm{mol})$ : monoclinic, space group $\mathrm{P} 2{ }_{1}$, $a=8.0807(2) \AA, b=10.5548(2) \AA, c=8.3669(2) \AA, \alpha=90^{\circ}, \beta=93.743(2)^{\circ}, \gamma=90^{\circ}$, $V=712.09(3) \AA^{3}, Z=2$, Crystal size $0.25 \times 0.2 \times 0.02 \mathrm{~mm}^{3}, T=149.98(10) \mathrm{K}$, $\mu(\mathrm{CuK} \alpha)=0.055 \mathrm{~mm}^{-1}, D_{\text {calc }}=0.068 \mathrm{~g} / \mathrm{cm}^{3}, 6306$ reflections measured, 2765 unique $\left(R_{\text {int }}=0.0384, R_{\text {sigma }}=0.0323\right)$, which were used in all calculations. The final $R_{1}$ was 0.0402 $(I>2 \sigma(I))$ and $w R_{2}$ was 0.1178 . The Flack parameter was $0.13(15)$, and the Hooft parameter was 0.16(9). Goodness of fit on $F^{2}$ was 1.069. CCDC 2116974.

Compound 7: $\mathrm{C}_{15} \mathrm{H}_{18} \mathrm{O}_{7}(\mathrm{Mr}=310.30 \mathrm{~g} / \mathrm{mol})$ : monoclinic, space group $\mathrm{P} 2_{1} / \mathrm{c}$, $a=11.3702(3) \AA, \mathrm{b}=7.30602(17) \AA, \mathrm{c}=16.9135(5) \AA, \alpha=90^{\circ}, \beta=108.413(3)^{\circ}$, $\gamma=90^{\circ}, V=1333.09(7) \AA^{3}, Z=4$, Crystal size $0.3 \times 0.25 \times 0.08 \mathrm{~mm}^{3}, T=150.00(10) \mathrm{K}$, $\mu(\mathrm{Cu} \mathrm{K} \alpha)=1.047 \mathrm{~mm}^{-1}, D_{\text {calc }}=1.5460 \mathrm{~g} / \mathrm{cm}^{3}, 3935$ reflections measured, 2546 unique $\left(R_{\text {int }}=0.0295, R_{\text {sigma }}=0.0370\right)$, which were used in all calculations. The final $R_{1}$ was 0.0520 $(I>=2 u(I))$ and $\omega R_{2}$ was 0.1591. Goodness of fit on $F^{2}$ was 1.058. CCDC 2116976 .

\subsection{Calculation of the ECD Spectra}

Merck molecular force field (MMFF) and DFT/TD-DFT calculations were carried out with the Spartan'14 software package (Wavefunction Inc., Irvine, CA, USA) and the Gaussian 09 program, respectively. MMFF conformational search generated low-energy conformers within a $10 \mathrm{kcal} \cdot \mathrm{mol}^{-1}$ energy window and optimized using PM6 semi-empirical optimizations. Then, each conformer was optimized with HF/6-31G(d) method in Gaussian09. Further optimization was performed at the b3lyp/6-311 $\mathrm{g}^{* *}$ level. The frequency was calculated at the same level to confirm each optimized conformer with the true minimum and to estimate their relative thermal free energies $(\Delta \mathrm{G})$ at $298.15 \mathrm{~K}$. The optimized conformers were continually used for the ECD calculations in methanol, which were carried out with Gaussian09 (b3lyp/6-311g**). Solvent effects were taken into account by using the polarizable continuum model (PCM). The ECD data were generated by the program SpecDis using a Gaussian band shape with $0.30 \mathrm{eV}$ exponential half-width from dipolelength dipolar and rotational strengths, and the final ECD spectrum was drawn by Origin 2018. All calculations were performed by Tianhe- 2 of the National Super Computer Center in Guangzhou.

\subsection{Anti-Glioma Activity}

The human glioma cell lines, T98G, U87MG, and U251, were purchased from the Cell Bank of the Chinese Academy of Sciences. Cells were cultured in Dulbecco's Modified Eagle's Medium (DMEM, Gibco, Carlsbad, CA, USA), containing 10\% fetal bovine serum (FBS), $100 \mathrm{IU} / \mathrm{mL}$ penicillin, $100 \mu \mathrm{g} / \mathrm{mL}$ streptomycin (all from Gibco, Carlsbad, CA, USA) in a cell incubator with $5 \% \mathrm{CO}_{2}$ at $37^{\circ} \mathrm{C}$.

Cell proliferation was analyzed by MTT according to the manufacturer's instructions. Briefly, T98G, U87MG, and U251 were digested and seeded at $1 \times 10^{3}$ cells/well in 96-well plates and cultured in $100 \mu \mathrm{L}$ medium overnight. The cells were treated by tested compounds with gradient concentrations for $48 \mathrm{~h}$. At each indicated time point, MTT solution $(10 \mu \mathrm{L} /$ well $)$ was added and then incubated at $37^{\circ} \mathrm{C}$ for $2 \mathrm{~h}$. The optical density (OD) at $450 \mathrm{~nm}$ was recorded by a microplate reader (Multiskan GO, Thermo Scientific, Waltham, MA, USA). Each experiment was performed three times.

\subsection{Anti-Inflammatory Activity}

RAW 264.7 cells were seeded in 96-well plates at a density of $5 \times 10^{5}$ cells $/ \mathrm{mL}$. After $12 \mathrm{~h}$, the cells were treated with $1 \mu \mathrm{g} / \mathrm{mL}$ of LPS and tested samples, followed by additional incubation for $24 \mathrm{~h}$ at $37^{\circ} \mathrm{C}$. MTT stock solution $(2 \mathrm{mg} / \mathrm{mL})$ was added to wells for a total reaction volume of $100 \mu \mathrm{L}$. After $4 \mathrm{~h}$ incubation, the supernatants were aspirated. The formazan crystals in each well were dissolved in DMSO $(100 \mu \mathrm{L})$, and the absorbance was measured with the wavelength of $490 \mathrm{~nm}$ by a microplate reader (Multiskan GO, Thermo Scientific). The data were expressed as mean percentages of the viable cells compared to the respective control. After pre-incubation of RAW 264.7 cells $\left(1.5 \times 10^{5}\right.$ cells $\left./ \mathrm{mL}\right)$ 
with $1 \mu \mathrm{g} / \mathrm{mL}$ LPS and samples at $37{ }^{\circ} \mathrm{C}$ for $24 \mathrm{~h}$, the quantity of nitrite accumulated in the culture medium was measured as an indicator of $\mathrm{NO}$ production. Briefly, cell culture medium $(50 \mu \mathrm{L})$ was added with Griess reagent $(100 \mu \mathrm{L})$ and incubated at room temperature for $10 \mathrm{~min}$. The absorbance was measured by a microplate reader (Multiskan GO, Thermo Scientific, Waltham, MA, USA) at $540 \mathrm{~nm}$ wavelength.

\section{Conclusions}

The chemical investigation of the ascidian-derived fungus Diaporthe sp. SYSU-MS4722 afforded seven new polyketides, diaporthones $A-G(\mathbf{1}-\mathbf{7})$, together with 13 known analogues, including five mono- (8-14) and six dimeric xanthones (15-20). The absolute configurations of 1-7 were identified by X-ray crystallographic analysis and Calculation of the ECD Spectra. Compounds 11 and 15-20 showed significant anti-inflammatory activity with inhibition of nitric oxide (NO) production in RAW264.7 cells activated by lipopolysaccharide with $\mathrm{IC}_{50}$ values between 6.3 and $8.0 \mu \mathrm{M}$. At the same time, dimeric xanthones (15-20) exhibited selectively growth-inhibitory effects on T98G cell lines with $\mathrm{IC}_{50}$ values ranging from 19.5 to $78.0 \mu \mathrm{M}$.

Supplementary Materials: The following are available online at https://www.mdpi.com/article/10 .3390/md20010051/s1, Figure S1: The HRESIMS spectrum of compound 1, Figures S2-S7: The 1D and 2D NMR (600 MHz) spectra of compound 1 in $\mathrm{CD}_{3} \mathrm{OD}$, Figure S8: The IR spectrum of compound 1, Figure S9: The HRESIMS spectrum of compound 2, Figures S10-S15: The 1D and 2D NMR (400 $\mathrm{MHz}$ ) spectra of compound 2 in $\mathrm{CD}_{3} \mathrm{OD}$, Figure S16: The IR spectrum of compound 2, Figure S17: The HRESIMS spectrum of compound 3, Figures S18-S23: The 1D and 2D NMR (400 MHz) spectra of compound 3 in acetone- $d_{6}$, Figure S24: The IR spectrum of compound 3, Figure S25: The HRESIMS spectrum of compound 4, Figures S26-S31: The 1D and 2D NMR (400MHz) spectra of compound 4 in $\mathrm{CD}_{3} \mathrm{OD}$, Figure S32: The IR spectrum of compound 4, Figure S33: The HRESIMS spectrum of compound 5, Figures S34-S39: The 1D and 2D NMR (400 MHz) spectra of compound 5 in $\mathrm{CD}_{3} \mathrm{OD}$, Figure S40: The IR spectrum of compound 5, Figure S41: The HRESIMS spectrum of compound 6, Figures S42-S47: The 1D and 2D NMR (400 MHz) spectra of compound 6 in $\mathrm{CDCl}_{3}$, Figure S48: The IR spectrum of compound 6, Figure S49: The HRESIMS spectrum of compound 7, Figures S50-S55: The 1D and 2D NMR (400MHz) spectra of compound 7 in $\mathrm{CD}_{3} \mathrm{OD}$, Figure S56: The IR spectrum of compound 7.

Author Contributions: Conceptualization, S.C. and L.L.; methodology, S.C. and H.G.; validation, S.C., H.G., and H.S.; formal analysis, M.J.; investigation, S.C.; resources, L.L. and J.L.; data curation, Q.W.; writing-original draft preparation, S.C. and H.S. writing-review and editing, S.C.; project administration, S.C.; funding acquisition, S.C. and L.L. All authors have read and agreed to the published version of the manuscript.

Funding: This work was supported by the National Natural Science Foundation of China (Grant No. 41806155, U20A2001), Science and Technology Innovation Special Fund of Zhuhai City (Grant No. ZH22017003200020PWC), the Fundamental Research Funds for the Natural Science Foundation of Guangdong Province (Grant No. 2018A030310304), the National Key R\&D Program of China (Grant No. 2019YFC0312501), the Key-Area Research, and Development Program of Guangdong Province (Grant No. 2020B1111030005).

Acknowledgments: We acknowledge S.G., Y.L., and L.F. of Test Center, Sun Yat-sen University to help us to finish the spectra test.

Conflicts of Interest: The author declare no conflict of interest.

\section{References}

1. Weller, M.; Wick, W.; Aldape, K.; Brada, M.; Berger, M.; Pfister, S.M.; Nishikawa, R.; Rosenthal, M.; Wen, P.Y.; Stupp, R.; et al. Glioma. Nat. Revs. Dis. Primers 2015, 1, 15017. [CrossRef]

2. Bray, F.; Ferlay, J.; Soerjomataram, I.; Siegel, R.L.; Torre, L.A.; Jemal, A. Global cancer statistics 2018: GLOBOCAN estimates of incidence and mortality worldwide for 36 cancers in 185 countries. CA Cancer J. Clin. 2018, 68, 394-424. [CrossRef] [PubMed]

3. Lapointe, S.; Perry, A.; Butowski, N.A. Primary brain tumours in adults. Lancet 2018, 392, 432-446. [CrossRef] 
4. Zhao, P.; Wang, Y.; Kang, X.; Wu, A.; Yin, W.; Tang, Y.; Wang, J.; Zhang, M.; Duan, Y.; Huang, Y. Dual-targeting biomimetic delivery for anti-glioma activity via remodeling the tumor microenvironment and directing macrophage-mediated immunotherapy. Chem. Sci. 2018, 9, 2674-2689. [CrossRef]

5. Chen, S.; Shen, H.; Zhang, P.; Cheng, H.; Dai, X.; Liu, L. Anti-glioma trichobamide A with an unprecedented tetrahydro-5Hfuro[2,3-b]pyrrol-5-one functionality from ascidian-derived fungus Trichobotrys effuse 4729. Chem Commun. 2019, 55, 1438-1441. [CrossRef]

6. Yan, Y.; Xu, Z.; Dai, S.; Qian, L.; Sun, L.; Gong, Z. Targeting autophagy to sensitive glioma to temozolomide treatment. J. Exp. Clin. Cancer Res. 2016, 35, 23. [CrossRef]

7. Chen, X.; Zhang, M.; Gan, H.; Wang, H.; Lee, J.H.; Fang, D.; Kitange, G.J.; He, L.; Hu, Z.; Parney, I.F.; et al. A novel enhancer regulates MGMT expression and promotes temozolomide resistance in glioblastoma. Nat. Commun. 2018, 9, 2949. [CrossRef]

8. Pereira, R.B.; Evdokimov, N.M.; Lefranc, F.; Valentão, P.; Kornienko, A.; Pereira, D.M.; Andrade, P.B.; Gomes, N.G.M. Marinederived anticancer agents: Clinical benefits, innovative mechanisms, and new targets. Mar. Drugs 2019, 17, 329. [CrossRef]

9. Di, K.; Lloyd, G.K.; Abraham, V.; MacLaren, A.; Burrows, F.J.; Desjardins, A.; Trikha, M.; Bota, D.A. Marizomib activity as a single agent in malignant gliomas: Ability to cross the blood-brain barrier. Neuro-Oncol. 2016, 18, 840-848. [CrossRef]

10. Reed, K.A.; Manam, R.R.; Mitchell, S.S.; Xu, J.; Teisan, S.; Chao, T.H.; Deyanat-Yazdi, G.; Neuteboom, S.T.; Lam, K.S.; Potts, B.C. Salinosporamides D-J from the marine actinomycete Salinispora tropica, bromosalinosporamide, and thioester derivatives are potent inhibitors of the 20S proteasome. J. Nat. Prod. 2007, 70, 269-276. [CrossRef] [PubMed]

11. Feling, R.H.; Buchanan, G.O.; Mincer, T.J.; Kauffman, C.A.; Jensen, P.R.; Fenical, W. Salinosporamide A: A highly cytotoxic proteasome inhibitor from a novel microbial source, a marine bacterium of the new genus salinospora. Angew. Chem. Int. Ed. 2003, 42, 355-357. [CrossRef]

12. Senter, P.D.; Sievers, E.L. The discovery and development of brentuximab vedotin for use in relapsed Hodgkin lymphoma and systemic anaplastic large cell lymphoma. Nat. Biotech. 2012, 30, 631-637. [CrossRef] [PubMed]

13. Niaz, S.I.; Zhang, P.; Shen, H.; Li, J.; Chen, B.; Chen, S.; Liu, L.; He, J. Two new isochromane derivatives penisochromanes A and B from ascidian-derived fungus Penicillium sp. 4829. Nat. Prod. Res. 2019, 33, 1262-1268. [CrossRef]

14. Chen, S.; Jiang, M.; Chen, B.; Salaenoi, J.; Niaz, S.I.; He, J.; Liu, L. Penicamide A, A Unique N,N'-Ketal Quinazolinone Alkaloid from Ascidian-Derived Fungus Penicillium sp. 4829. Mar. Drugs 2019, 17, 522. [CrossRef]

15. Chen, S.; Shen, H.; Deng, Y.; Guo, H.; Jiang, M.; Wu, Z.; Yin, H.; Liu, L. Roussoelins A and B: Two phenols with antioxidant capacity from ascidian-derived fungus Roussoella siamensis SYSU-MS4723. Mar. Life Sci. Technol. 2021, 3, 69-76. [CrossRef]

16. Jiang, M.; Wu, Z.; Wu, Q.; Yin, H.; Guo, H.; Yuan, S.; Liu, Z.; Chen, S.; Liu, L. Amphichoterpenoids A-C, unprecedented picoline-derived meroterpenoids from the ascidian-derived fungus Amphichorda felina SYSU-MS7908. Chin. Chem. Lett. 2021, 32, 1893-1896. [CrossRef]

17. Flack, H.D.; Bernardinelli, G. The use of X-ray crystallography to determine absolute configuration. Chirality 2008, 20, 681-690. [CrossRef]

18. Hooft, R.W.; Straver, L.H.; Spek, A.L. Determination of absolute structure using Bayesian statistics on Bijvoet differences. J. Appl. Crystallogr. 2008, 41, 96-103. [CrossRef] [PubMed]

19. Guo, H.; Liu, Z.-M.; Chen, Y.-C.; Tan, H.-B.; Li, S.-N.; Li, H.-H.; Gao, X.-X.; Liu, H.-X.; Zhang, W.-M.J.M.D. Chromone-derived polyketides from the deep-sea fungus Diaporthe phaseolorum FS431. Mar. Drugs 2019, 17, 182. [CrossRef]

20. Hu, H.-B.; Luo, Y.-F.; Wang, P.; Wang, W.-J.; Wu, J. Xanthone-derived polyketides from the Thai mangrove endophytic fungus Phomopsis sp. xy21. Fitoterapia 2018, 131, 265-271. [CrossRef] [PubMed]

21. Cao, S.; McMillin, D.W.; Tamayo, G.; Delmore, J.; Mitsiades, C.S.; Clardy, J. Inhibition of tumor cells interacting with stromal cells by xanthones isolated from a Costa Rican Penicillium sp. J. Nat. Prod. 2012, 75, 793-797. [CrossRef]

22. Hou, X.-M.; Wang, C.-Y.; Gu, Y.-C.; Shao, C.-L. Penimethavone A, a flavone from a gorgonian-derived fungus Penicillium chrysogenum. Nat. Prod. Res. 2016, 30, 2274-2277. [CrossRef]

23. Krick, A.; Kehraus, S.; Gerhäuser, C.; Klimo, K.; Nieger, M.; Maier, A.; Fiebig, H.-H.; Atodiresei, I.; Raabe, G.; Fleischhauer, J.; et al. Potential cancer chemopreventive in Vitro activities of monomeric xanthone derivatives from the marine algicolous fungus Monodictys putredinis. J. Nat. Prod. 2007, 70, 353-360. [CrossRef]

24. Jin, Y.; Qin, S.; Gao, H.; Zhu, G.; Wang, W.; Zhu, W.; Wang, Y. An anti-HBV anthraquinone from aciduric fungus Penicillium sp. OUCMDZ-4736 under low pH stress. Extremophiles 2018, 22, 39-45. [CrossRef] [PubMed]

25. Rönsberg, D.; Debbab, A.; Mándi, A.; Vasylyeva, V.; Böhler, P.; Stork, B.; Engelke, L.; Hamacher, A.; Sawadogo, R.; Diederich, M.; et al. Pro-Apoptotic and Immunostimulatory tetrahydroxanthone dimers from the endophytic fungus Phomopsis longicolla. J. Org. Chem. 2013, 78, 12409-12425. [CrossRef] [PubMed]

26. Isaka, M.; Jaturapat, A.; Rukseree, K.; Danwisetkanjana, K.; Tanticharoen, M.; Thebtaranonth, Y. Phomoxanthones A and B, novel xanthone dimers from the endophytic fungus Phomopsis species. J. Nat. Prod. 2001, 64, 1015-1018. [CrossRef]

27. Wagenaar, M.M.; Clardy, J. Dicerandrols, new antibiotic and cytotoxic dimers produced by the fungus Phomopsis 1 ongicolla Isolated from an endangered mint. J. Nat. Prod. 2001, 64, 1006-1009. [CrossRef]

28. Rukachaisirikul, V.; Sommart, U.; Phongpaichit, S.; Sakayaroj, J.; Kirtikara, K. Metabolites from the endophytic fungus Phomopsis sp. PSU-D15. Phytochemistry 2008, 69, 783-787. [CrossRef] [PubMed]

29. Kjer, J.; Debbab, A.; Aly, A.H.; Proksch, P. Methods for isolation of marine-derived endophytic fungi and their bioactive secondary products. Nat. Protoc. 2010, 5, 479-490. [CrossRef] [PubMed] 